\title{
1 Title:Ice records provide new insights into climatic vulnerability of 2 Central Asian forest and steppe communities
}

3

4 Short title: Vulnerability of forest-steppe communities

5 Authors: Sandra O. Brugger ${ }^{\mathrm{a}, \mathrm{b}}$, Erika Gobet ${ }^{\mathrm{a}, \mathrm{b}}$, Michael Sigl ${ }^{\mathrm{b}, \mathrm{c}}$, Dimitri Osmont ${ }^{\mathrm{b}, \mathrm{c}, \mathrm{d}}$, Tatyana $6 \quad$ Papina $^{\mathrm{e}}$, Natalia Rudaya ${ }^{\mathrm{f}, \mathrm{g}}$, Margit Schwikowski ${ }^{\mathrm{b}, \mathrm{c}, \mathrm{d}}$, Willy Tinner ${ }^{\mathrm{a}, \mathrm{b}}$

$7 \quad$ Institute of Plant Sciences, University of Bern, Switzerland

8 beschger Center for Climate Change Research, University of Bern, Switzerland

9 'Paul Scherrer Institute, Villigen, Switzerland

10 department for Chemistry and Biochemistry, University of Bern, Switzerland

11 'Institute for Water and Environmental Problems, SB RAS, Barnaul, Russia

12 fInstitute of Archaeology and Ethnography, SB RAS, Novosibirsk, Russia

13 'University of Potsdam, Germany

14

15 Contact corresponding author: Address: Institute of Plant Sciences, Altenbergrain 21, CH-3013

16 Bern, email: sandra.bruegger@ips.unibe.ch, phone: +41 792887352

17 Keywords: Boreal forest diebacks, Climatic tipping points, Diversity, Ice core, Moisture 18 change, Pollen, Microscopic charcoal, SCP

19

20 Declarations of interest: none 
Forest and steppe communities in the Altai region of Central Asia are threatened by changing climate and anthropogenic pressure. Specifically, increasing drought and grazing pressure may cause collapses of moisture-demanding plant communities, particularly forests. Knowledge about past vegetation and fire responses to climate and land use changes may help anticipating future ecosystem risks, given that it has the potential to disclose mechanisms and processes that govern ecosystem vulnerability. We present a unique paleoecological record from the highalpine Tsambagarav glacier in the Mongolian Altai that provides novel large-scale information on vegetation, fire and pollution with an exceptional temporal resolution. Our palynological record identifies several late-Holocene boreal forest expansions, contractions and subsequent recoveries. Maximum forest expansions occurred at 3000-2800 BC, 2400-2100 BC, and 19001800 BC. After 1800 BC mixed boreal forest communities irrecoverably declined. Fires reached a maximum at 1600 BC, 200 years after the final forest collapse. Our multiproxy data suggest that burning peaked in response to dead biomass accumulation resulting from forest diebacks. Vegetation and fire regimes partly decoupled from climate after $1700 \mathrm{AD}$, when atmospheric industrial pollution began, and land use intensified. We conclude that moisture availability was more important than temperature for past vegetation dynamics, in particular for forest loss and steppe expansion. The past Mongolian Altai evidence implies that in the future forests of the Russian Altai may collapse in response to reduced moisture availability. 


\section{INTRODUCTION}

Forest disruption has substantially increased globally in recent years (McDowell \& Allen, 2015). The vast boreal forests and forest steppes in and around the Altai region in Central Asia provide an important terrestrial carbon storage but respond highly sensitive to recent global change (Sato et al., 2007; Liu et al., 2013; Chenlemuge et al., 2013; Tian et al., 2013; 2014; Hijioka et al., 2014; Dulamsuren et al., 2016; Khansaritoreh et al., 2017; Zaoh et al., 2018). In the past decades, the Altai region experienced rising temperatures combined with increasing extreme events such as prolonged heatwaves, drought periods and short-term heavy rainfall events (Lkhagvadorj et al., 2013). As boreal forest growth is not only limited by temperature but also by moisture availability, the forests progressively suffer from water constraints (Dulamsuren et al., 2010; 2014). The establishment, persistence and decline of these boreal forests depend on soil moisture availability which is not only constrained by precipitation, but also by the local soil development and its water-holding capacity (Henne et al., 2011) that is extremely low for the predominant soil types in the region.

The central position of the Altai Mountains between the vast Siberian Taiga forests in the north and the Gobi desert in the south results in a steep climatic and vegetation gradient with fragmented and diverse habitats including many rare and endemic species (Rudaya et al., 2008). Their natural resources such as forests, productive grasslands, and fresh water sources have attracted Central Asian nomadic groups since centuries (Rudaya et al., 2008). In recent years, these ecotonal mountain steppe ecosystems experienced rapid degradation through overgrazing, systematic logging, dead wood collecting and human-set fires (Tsogtbaatar, 2004; Dulamsuren et al., 2014). Anthropogenic pressure combined with growing moisture deficiency may cause irreversible forest vegetation loss, reduce steppe pasture productivity and thus alter species composition and diversity (Lkhagvadorj et al., 2013).

Knowledge about past vegetation dynamics in the Mongolian Altai contributes to a better understanding of future ecosystem responses to climate change and human land use, and may assist forest, grassland and fire management strategies by providing baselines of past ecosystem 
variability in response to strong environmental change. However, paleo records that provide information about Holocene vegetation and fire history are scarce, lack temporal resolution and/or chronological precision (Tarasov et al., 2000; Gunin et al., 2009; Rudaya et al., 2009; Umbanhowar et al., 2009; Unkelbach et al., 2018). Such limitations impede a thorough assessment of ecosystem resilience and vulnerability. The snow-capped Tsambagarav Mountain provides a regional to supra-regional ice archive of ecosystem change, which is well suited to reconstruct ecosystem dynamics with high temporal resolution and precision (Herren et al., 2009). Here we address persisting knowledge gaps with the following aims: (1) for the first time, we use microscopic charcoal to reconstruct the fire dynamics in the Mongolian Altai; (2) pollen, spores and spheroidal carbonaceous particles are used to investigate the long-term linkages between the fire regime, vegetation, land use, and pollution; (3) we use the palynological information including charcoal to assess ecosystem response variability to climate change, and (4) evidence from other studies is used to underscore the spatio-temporal relevance of our outcomes and to derive implications for ecosystem responses under globalchange conditions.

\section{STUDY SITE}

The Altai Mountains stretch over ca. 1200 km, crossing the borders of Russia, Mongolia, Kazakhstan, and China. With 4500 m a.s.l. maximum elevation (Mount Belukha in Russia, Fig. 1A) the Altai Mountains build a continental climate barrier for air masses from northwest, resulting in a strong northwest $\left(800 \mathrm{~mm} \mathrm{year}^{-1}\right)$ to southeast $\left(<200 \mathrm{~mm}^{\text {year }}{ }^{-1}\right)$ precipitation gradient (Klinge et al., 2003) given that the moisture source in the region are the Westerlies. The extreme continental climate is dominated by the Siberian High with cold dry winters and precipitation prevailing in June to August (Klinge et al., 2003). The investigated ice archive on Tsambagarav Mountain is located in the Mongolian Bayan-Ölgii province (Fig. 1A), a region with very dry climatic conditions (annual precipitation ca. $200 \mathrm{~mm}$ at $1700 \mathrm{~m}$ a.s.l.). 

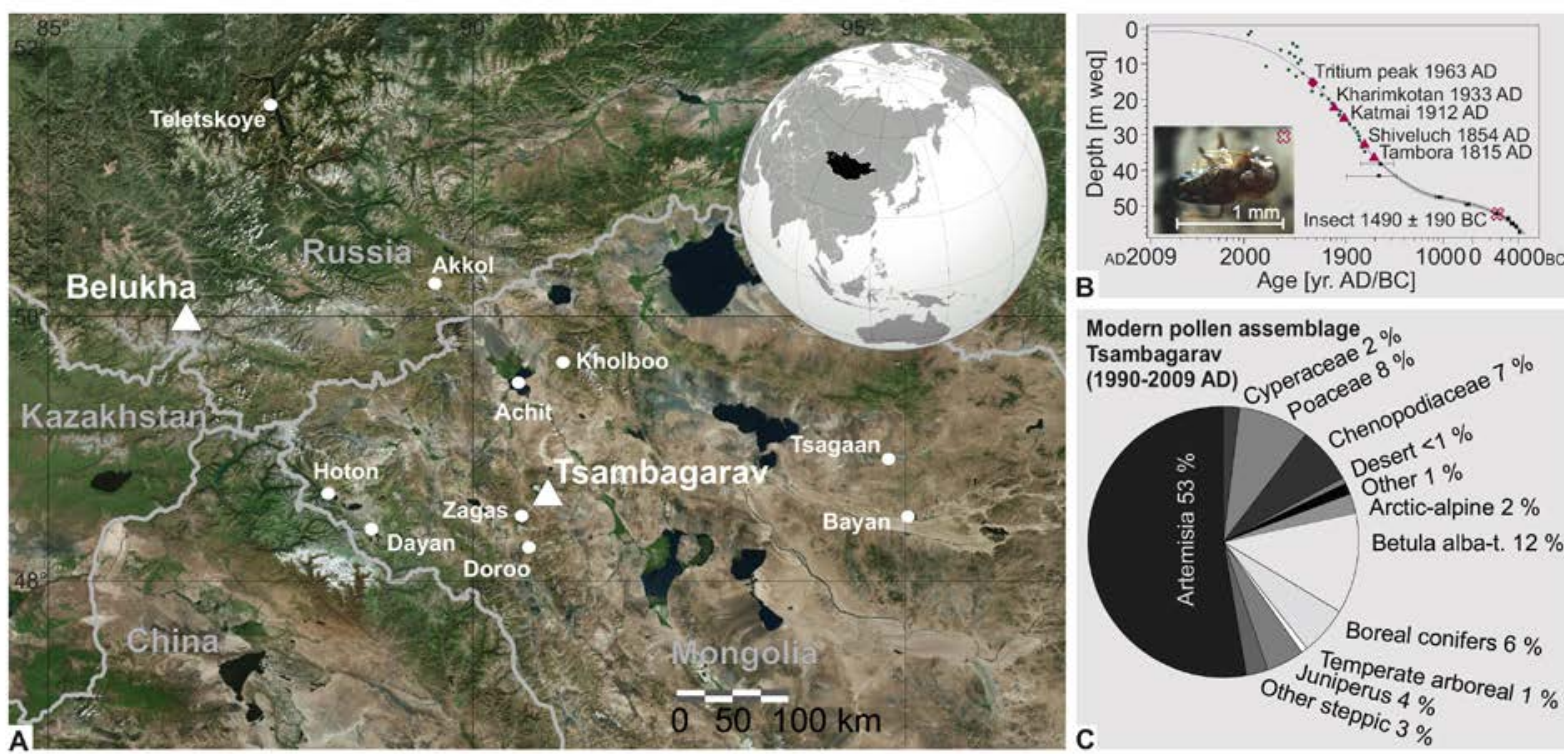

Figure 1 Study area, chronology and modern pollen deposition at Tsambagarav glacier. Panel A: Map of the Altai region with glacier records (triangle) and selected records of fire and vegetation reconstructions (white dots), map modified (source of satellite images: U.S. Geological Survey). Panel B: Chronology of Tsambagarav record based on a glacier flow model (blue dashed line), annual layer counting (2009-1815 AD), maximum tritium peak (red diamond), volcanic layers (red triangles) and ${ }^{210} \mathrm{~Pb}$ activity (green circles). From $1815 \mathrm{AD}$ modeled ages as exponential equation (black dashed line) with upper and lower limit of the equation (gray shaded) based on ${ }^{14} \mathrm{C}$ - dating of water-insoluble organic carbon of atmospheric origin (black squares with uncertainty bars). Insert: ${ }^{14} \mathrm{C}$-date of an insect remain (red cross and photo, Uglietti et al., 2016). Figure adapted from Herren et al. (2013). Panel C: Modern pollen assemblage in Tsambagarav glacier ice (average over 20 years as percentages of the terrestrial pollen sum).

Geologically, the Mongolian Altai consists of siliceous bedrock, including schists and granites with Leptosols as prevailing soil type that are susceptible to erosion and desiccation (Dulamsuren et al., 2014). The modern vegetation around Tsambagarav reflects the cold semiarid continental climate characterized by huge differences in maximum and minimum daily and yearly temperatures (July average $+22.7^{\circ} \mathrm{C}$, January average $-22.6^{\circ} \mathrm{C}$ at Ölgii weather station; NOAA, 2013). Gradients such as altitude and exposure lead to pronounced local differences in growth season length, heat sum, precipitation, and soil formation, which together strongly affect species distribution and productivity (Rudaya et al., 2009).

Wide areas at high elevations surrounding Tsambagarav are occupied by cryo-xerophyllic communities with Betula nana ssp. rotundifolia (synonyms Betula nana subsp. rotundifolia

114 (Spach) Malyschev, Betula glandulosa Michaux subsp. rotundifolia (Spach) Regel, and Betula 115 rotundifolia Spach, see TPL, 2018; Gunin et al., 2009), Salix glauca, Kobresia, and Potentilla sericea become more abundant with increasing altitude and may penetrate up to $3000 \mathrm{~m}$ a.s.l. 

and Thalictrum alpinum are increasingly fragmented above $3200 \mathrm{~m}$ a.s.l. Sedum algidum is

119 found up to the nival zone close to the eternal snow margin (Walter, 1974), which is at Tsambagarav between 3000 to 3800 m a.s.l. depending on the exposure (Herren et al., 2013). Below 1800-2000 m a.s.l. the mountain steppes are gradually replaced by dry Stipa-Artemisia steppe communities with Stipa glareosa, S. gobica, Allium, Tanacetum, Artemisia species, and Caragana (Walter, 1974; Gunin et al., 2009). Anabasis brevifolia (Chenopodiaceae) is the most common halophilous taxon in the region. Desert-steppe communities composed of Stipa sp. and Salsola dominate in dry isolated valleys and southeast of Tsambagarav in the large mountain depression "basin of the large lakes", where precipitation is further reduced to $<200 \mathrm{~mm}_{\text {year}}{ }^{-1}$ (Gunin et al., 2009). Wet herbaceous communities and small woody stands with Betula pendula, Populus tremula, Salix, and Alnus glutinosa grow along streams (Walter, 1974; Gunin et al., 2009; Stritch et al., 2014). The closest of these parklands with dozens of $\mathrm{km}^{2}$ sizes occur ca. $50 \mathrm{~km}$ northwest of Tsambagarav.

The mid-elevation forest belt in the Mongolian Altai is restricted to north facing slopes in the western (Hoton Nur area, Fig. 1A) and northwestern part of the Mongolian Altai between 1900-2100 m a.s.l., while on south facing slopes, mountain steppe communities directly pass over to alpine plant communities. The narrow and discontinuous forest belts are composed of Pinus sibirica, Larix sibirica, Betula pendula. Picea obovata co-occurs where soil moisture is sufficient (Walter, 1974; Gunin et al., 2009). In these forest stands at ca. $100 \mathrm{~km}$ distance from Tsambagarav, the upper limit of tree growth is controlled by summer temperature and the lower

138 limit by moisture availability and anthropogenic pressure such as logging activities (Klinge et 139 al., 2003; Lkhagvadorj et al., 2013; Tsogtbaatar, 2013). Floristically, the Mongolian forest 140 relicts belong to the forests in the Russian Altai (Walter, 1974) which consist of Pinus sibirica, 141 Abies sibirica, Larix sibirica and Betula pendula that form a dense boreal forest belt between 142 ca. 1000 and 2000 m a.s.l. in the region north of the Belukha glacier (see Fig. 1A; Walter, 1974; 143 Eichler et al., 2011). Below $1000 \mathrm{~m}$ a.s.l the Russian Altai is characterized by lowland feather- 
144

145

146

147

148

149

150

151

152

153

154

155

156

157

158

159

160

161

162

163

164

165

166

167

168

169

grass steppes (Stipa, other Poaceae, Artemisia, and Chenopodiaceae; Walter, 1974). Modern

Pinus sylvestris and Abies sibirica distribution is restricted to the Russian and Kazakh Altai, ca. 150-200 km north of Tsambagarav (Gunin et al., 2009).

\section{MATERIAL AND METHODS}

\section{Ice material and microfossil analysis}

We analyzed samples from an existing ice core from Tsambagarav Mountain. The core was drilled on the eastern summit $\left(48^{\circ} 39.338^{\prime}\right.$ N, $90^{\circ} 50.826^{\prime}$ E; Fig. 1A) in July 2009 at an altitude of 4130 m a.s.l. (Herren et al., 2013). The drilling reached bedrock with a total ice core length of $72 \mathrm{~m}$ and a diameter of $8.2 \mathrm{~cm}$. Core segments of ca. $70 \mathrm{~cm}$ were transported frozen to the Paul Scherrer Institute (PSI) in Switzerland.

202 continuous samples spanning the time 3500 BC to 2009 AD (55.6-0 m weq = water equivalent, corrected for varying density) from the outer part of the ice core were taken for palynological analysis. The sampling resolution was 40-90 years (3500 BC-1200 AD), 20-30 years (1200-1650 AD), 10 years (1650-1700 AD), five years (1700-1985 AD), and one year (1985-2009 AD, merged to five years after analysis) using the chronology of Herren et al. (2013). An additional ${ }^{14} \mathrm{C}$-date from an insect remain found during palynological sampling confirmed the accuracy of the existing depth-age model (Fig. 1B; Uglietti et al., 2016). Each sample contained 200-400 g ice, except one sample with $45 \mathrm{~g}$ at $52.2 \mathrm{~m}$ weq. The microfossil extraction followed a protocol for ice sample preparation (Brugger et al., 2018). One Lycopodium tablet was added to each sample before lab treatment to estimate microfossil concentrations (Stockmarr, 1971). Due to strong thinning in the deeper part of the glacier caused by lateral ice flow, annual layers could not be identified before $1825 \mathrm{AD}$, preventing influx calculations with a reasonable time resolution.

We use pollen and spores to infer vegetation history and the coprophilous fungal spore Sporormiella as a proxy for herbivore grazing activity. A pollen sum of 500 was reached except in the samples of section 54-53 m weq (2600-2000 BC), where due to small pollen 
170

171

172

173

174

175

176

177

178

179

180

181

182

183

184

185

186

187

188

189

190

191

192

193

194

195

196

concentrations we reached 100 grains, which is above the minimum for reliable percentage calculations and environmental reconstructions (50 items; Heiri and Lotter, 2001). Pollen and spore identification under a light microscope at $400 \mathrm{x}$ magnification followed palynological keys (Huang, 1972; Moore et al., 1991; Beug, 2004) and the reference collection in Bern, Switzerland. Shrub type (referred to as Betula nana-type) and tree type Betula (Betula albatype) separation is based on the pore depth and the grain diameter to pore depth ratio (D/P) following Clegg et al. (2015). The palynological Betula distinction covers B. pubescens, B. pendula (both B. alba-type), B. glandulosa and B. nana (both B. nana-type) as well as other North American and Eurasian birch species (Birks, 1968; Clegg et al., 2015). Cerealia-type was classified according to Beug (2004). Although Artemisia comprises herb and shrub species, we include all Artemisia pollen in the herb pollen sum following Gunin et al. (2009) since pollen taxonomy allows no further discrimination. Pollen and spore data are presented as percentages of the terrestrial pollen sum.

Microscopic charcoal $>10 \mu \mathrm{m}$ is used as a proxy for fire activity (e.g. MacDonald et al., 1991; Tinner et al., 1998; Conedera et al., 2009; Adolf et al., 2017). We counted a minimum sum of 200 items (charcoal fragments and Lycopodium grains, Finsinger \& Tinner, 2005; Tinner \& Hu, 2003). If needed (low charcoal concentrations), we continued until a minimum of 20 charcoal fragments was reached. Subsequently, the $>90$ th percentile (= $10 \%$ upper charcoal concentration values over the entire record) was identified to infer regional fire activity peaks. SCP (= spheroidal carbonaceous particles) with a diameter $>10 \mu \mathrm{m}$ and clear features (Rose, 2015) were counted along pollen and spores to reconstruct industrial air pollution. All microfossil concentrations were standardized to one liter.

Annual layer thickness is highest in the uppermost part of the ice core, resulting in an exponential depth-age relationship (Fig. 1B). Thus, the temporal sampling resolution in the younger part is much higher compared to the older part of the ice core where the ice had thinned substantially (i.e. one to several hundred years per m weq with increasing core depth). These archive characteristics result in varying detection limits for rare microfossil types along the 
record for comparable time periods. We kept the original lab sampling resolution for the

198 interpretation of the palynological record (Figs 2-4) while we amalgamated samples of the

199 overview pollen and charcoal records to reach 40 to 50 years resolution in the younger part

200 (period 1100-2009 AD, Fig. 5). This resulted in comparable time steps along the sequence.

\section{Numerical analysis}

202 Optimal sum-of-squares partitioning was applied for zonation of the pollen data (Birks \& 203 Gordon, 1985). Subsequently, statistically significant local pollen assemblage zones (LPAZ) 204 were inferred with the broken stick approach (Bennett, 1996). Only LPAZ with more than two 205 samples were accepted to account for single microfossil deposition events reaching the exposed 206 high-alpine glacier site. We applied ordination methods to statistically summarize the pollen signal and to search for correlations with supplementary variables and similarities with external

matrix. Charcoal concentrations, fern spore and Sporormiella percentages of the Tsambagarav glacier (Eichler et al., 2011) were included as external samples (not influencing the ordination 214 dataset) to search for spatio-temporal similarities between the two sites. We amalgamated 215 Betula (includes Betula nana-type and Betula alba-type) and Chenopodiaceae (Salsola and remaining Chenopodiaceae) to homogenize the taxonomic resolution between the Tsambagarav 217 and Belukha data.

To our knowledge palynologically-based diversity measures (e.g. palynological richness, 219 evenness) are not available yet from the Altai region. To fill this gap we estimated palynological 220 richness (PRI) with rarefaction analysis as a proxy for species richness and the probability of 221 interspecific encounter (PIE) as a proxy for evenness (Birks \& Line, 1992; Hurlbert, 1971). The 222 minimum pollen sum for rarefaction analysis was 105 pollen grains. To account for evenness 
distortions of palynological richness we calculated PIE-detrended palynological richness (DEPRI; Colombaroli \& Tinner, 2013).

\section{RESULTS AND INTERPRETATION}

\section{Modern pollen composition reflects vegetation and pollen catchment}

The modern pollen concentration in the Tsambagarav record is ca. 6000 grains $\mathrm{l}^{-1}$ which corresponds to a total influx of 450 grains $\mathrm{cm}^{-2}$ year-1. This is very low compared to sedimentary archives. The largest amount derives from the steppic taxa Artemisia (53 \%), Poaceae (8 \%) and Chenopodiaceae (7 \%), with arboreal pollen (AP) of Betula alba-type (12 \%), Juniperus (4 \%), and conifers such as Pinus sibirica (6 \%; Fig. 1C). With $25 \%$ AP and $75 \%$ non-arboreal pollen (NAP) the pollen signal reflects the patchy modern regional vegetation dominated by dry herbaceous steppes with scattered boreal trees. The presence of conifer and Betula pollen indicates regional sources, as the closest parklands with Betula pendula (Betula alba-type pollen) occur at ca. $50 \mathrm{~km}$ northwestwards and forested areas around $100 \mathrm{~km}$ westwards in the Hoton Nur region (Fig. 1A). Single grains of warm-loving taxa (e.g. Castanopsis-type and Pistacia; Fig. 2) along the record indicate pollen transport by southern air masses over more than 1000 km, where Pistacia has its northern distribution limit today (Golan-Goldhirsh, 2009). Westerlies are the main moisture source for the Altai region. On the basis of the modern atmospheric pattern (Herren et al., 2013) we assume northwest as the predominant wind direction for our site during the mid and late Holocene. The historical pollen assemblages at Tsambagarav are clearly distinct from those from Belukha glacier in the Russian Altai ca. 320 km northwest (Fig. 1 A; Eichler et al., 2011). This finding suggests little overlap of the two glacier pollen catchments. Based on the pollen composition in the top sample of Tsambagarav and its comparison with vegetation composition in the study area (e.g. Walter 1974; Gunin et al., 2009) we assume that the Tsambagarav pollen signal derives from a catchment of ca. 60$200 \mathrm{~km}$ around the site, most likely with a strong northwest bias and with only occasional pollen grains deriving from longer distances. 
250 Six statistically significant local pollen assemblage zones (LPAZ) were identified along the 251 palynological record (Figs 2-3). We additionally divided TSA-3 and TSA-5 in two non252 significant subzones a and b. Results are presented as pollen percentages and pollen 253 concentrations (around 10’000 grains $\mathrm{l}^{-1}$ except the period 2900-1800 BC (zone TSA-3a) with 254 low concentrations $<2000$ grains $\mathrm{l}^{-1}$ ).

255 Pollen data in zone TSA-1 (3500-3100 BC) indicates that the vegetation was dominated by 256 herbaceous steppe communities, mainly composed of Artemisia (80 \%) with Poaceae, 257 Chenopodiaceae and other taxa growing in dry Stipa-Artemisia steppe communities (e.g. 258 Cyperaceae, Bupleurum-type, Galium-type; Fig. 2). The pollen record indicates that Salsola, a 259 key taxon of semi-desert environments occurring i.e. in sheltered valleys (Walter, 1974), was 260 also present. AP percentages are low (0-10\%) and mainly composed of Betula alba-type and 261 the dry adapted taxon Ephedra with single pollen grains of Pinus sylvestris-type and Pinus 262 sibirica. The conifer pollen suggests either presence of single conifers in locally favorable spots 263 in the herbaceous steppe or long-distance pollen transport. 


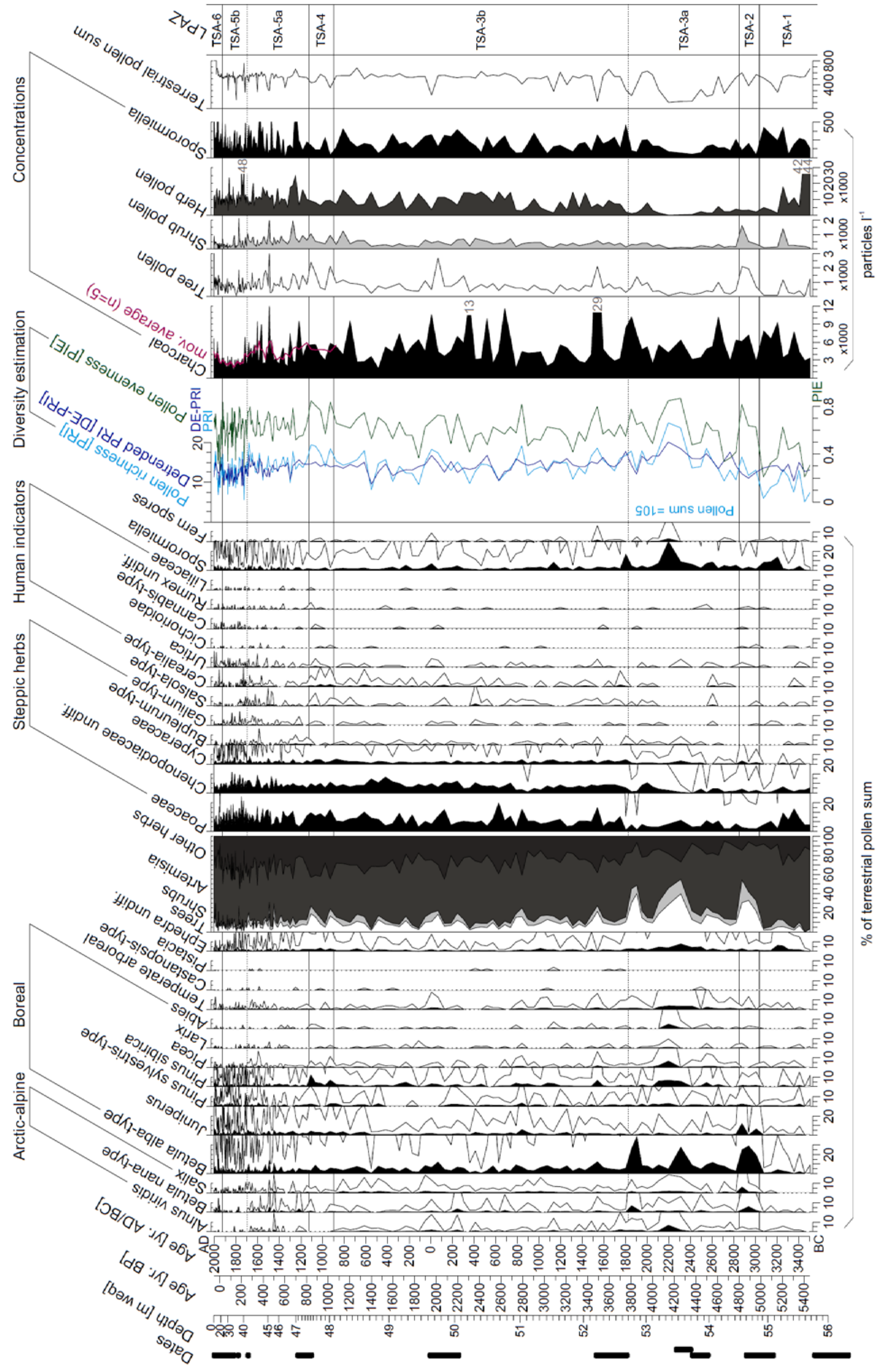


Figure 2 Percentage diagram of Tsambagarav ice core spanning the past $\mathbf{5 5 0 0}$ years. Selected pollen types, fern spores, and coprophilous fungal spores based on the terrestrial pollen sum. Temperate arboreal summary curve consists of Fagus, Corylus, Quercus and other temperate arboreal pollen taxa. Hollow curves $=10 \mathrm{x}$ exaggeration. Diversity estimation (Hurlbert, 1971) based on a minimum pollen sum of 105 for pollen richness (PRI), evenness-detrended pollen richness (DE-PRI), and evenness index (PIE). Concentration curves for charcoal, pollen and Sporormiella in particles $\mathrm{l}^{-1}$ and total terrestrial pollen sum. LPAZ = statistically significant local pollen assemblage zones, dashed lines not statistically significant. Chronology according to Herren et al. (2013), reference horizons in Fig. 1A.

Tree pollen percentages reach highest peaks between 3000 and 1800 BC (up to 50 \%; LPAZ TSA-2-TSA-3a; Fig. 2) indicating afforestation pulses in the steppes possibly resulting from moister and/or warmer conditions. Betula alba-type percentages (30\%) as well as tree pollen concentration peaks around 3000 and 1900 BC hint to periods with propitious environmental conditions that allowed expansion of the pioneer species. Pollen of the arctic-alpine shrub taxa Betula nana-type and Salix, as well as Juniperus reaches highest percentages of the entire record during this phase. This suggests an upward expansion of alpine tundra vegetation to altitudes higher than $3000 \mathrm{~m}$ a.s.l., which is today's upper altitudinal limit of alpine tundra shrubs such as Salix glauca and Betula nana ssp. rotundifolia in the area (Walter, 1974; Gunin et al., 2009). The second tree pollen peak between 2400 and 2100 BC is marked by an initial rise of Betula alba-type (20\%) followed by a second phase where pollen percentages of Pinus sibirica, Picea, Larix, Abies, and Alnus viridis increase, indicating a succession from primary Betula pendula-dominated forests to more diverse secondary forests and green alder thickets taxa is in China (Wu \& Raven, 1999). The forest expansions coincided with a spread of ferns (maximum fern spore percentages of the record). This period is further characterized by the 290 lowest pollen concentrations of the entire record $\left(<2000\right.$ grains $\left.\mathrm{l}^{-1}\right)$ that indicate diluted microfossil concentrations possibly caused by higher ice accumulation rates due to moister environments (Fig. 2, Herren et al., 2013). 


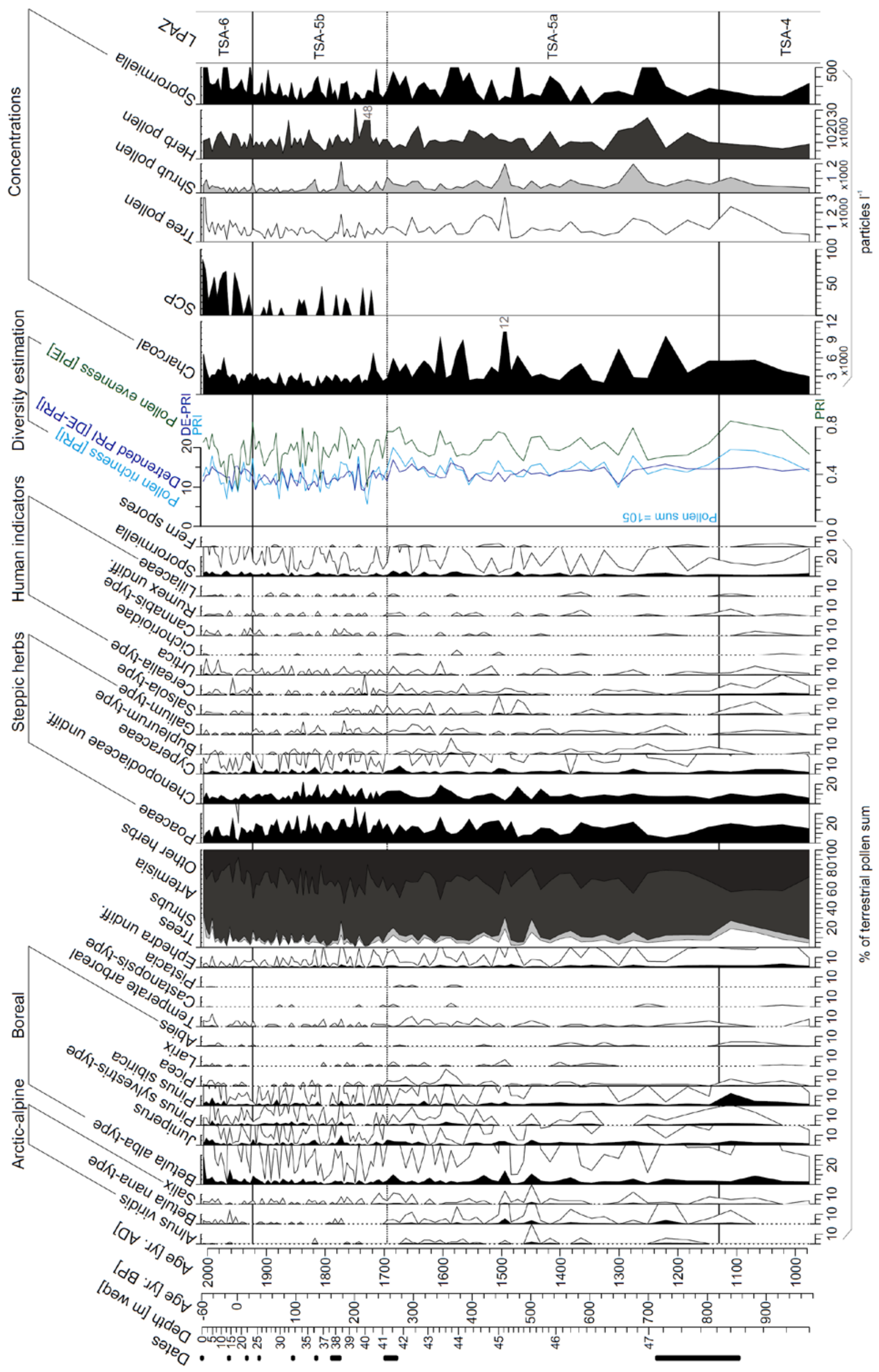


Figure 3 Percentage diagram of Tsambagarav ice core for the past millennium. Selected pollen types, fern spores, coprophilous fungal spores based on the terrestrial pollen sum. Temperate arboreal summary curve consists of Fagus, Corylus, Quercus and other temperate arboreal taxa. Hollow curves $=10 x$ exaggeration. Diversity estimation (Hurlbert 1971) based on a minimum pollen sum of 105 for pollen richness (PRI), evenness-detrended pollen richness (DE-PRI), and evenness index (PIE). Concentrations of charcoal, SCP (spheroidal carbonaceous particles), pollen, and Sporormiella in particles $\mathrm{l}^{-1}$. LPAZ $=$ statistically significant local pollen assemblage zones, dashed line not statistically significant. Chronology, presented ${ }^{14} \mathrm{C}$-dates and reference horizons (volcanic layers, drilling year, and tritium peak) according to Herren et al. (2013).

TSA-5b), pointing to several forest or arboreal vegetation retraction phases in the areas northwest and north of Tsambagarav. Dry Stipa-Artemisia steppe (e.g. Poaceae, Artemisia) as well as desert-steppe communities (e.g. increasing Chenopodiaceae and Salsola-type percentage values, Figs 2-3) expanded. The tree diebacks are defined by LPAZ boundaries indicating significant shifts in the vegetation around the glacier. A short-term Pinus sibirica pollen increase between 900 and 1100 AD (defined by LPAZ TSA-4) hints to a temporary establishment of the species in the catchment. Maximum landscape openness was reached after 1700 AD (AP <10 \%; Fig. 3). AP rises noticeably during LPAZ TSA-6 (1960-2009 AD) which is mainly due to increasing Betula alba-type and indicates rapid spreads of pioneer trees. associated with other pollen indicative of land use (e.g. Linum usitatissimum, Plantago lanceolota; Lang, 1994). Association with other adventive pollen (or less ideal apophytes pollen) is needed, because in entire Eurasia Cerealia-type pollen is occasionally produced by wild grass species (Beer et al., 2007; Van Zeist et al., 2016), e.g. by Trisetum spicatum, a common wild grass species of the Mongolian mountain steppes (Walter, 1974). Secondary anthropogenic pollen indicators such as Rumex crispus (R. acetosa-type), Cichorioideae, Urtica and Liliaceae prefer nutrient enriched former campsites suggesting pastoralism activities, 321 although they may occasionally also occur naturally on humid and nutrient-rich soils in the Mongolian Altai (Gunin et al., 2009). Thus, the presence and in particular the combined around $1000 \mathrm{AD}$, often in combination with Urtica, Rumex and Liliaceae. Cerealia-type pollen 
327 increase indicating intensified pastoralism activities (Gunin et al., 2009).

328 Dung fungal spores of Sporormiella are continuously present in large quantities along the entire record indicating continuous herbivore grazing in the steppes. The Sporormiella record suggests that herbivore grazing activities reached a maximum during the afforestation phase (20\% around $2200 \mathrm{BC}$ ). Increased grazing activity was possibly released by an enhanced productivity of the steppes related to increasing moisture, or less likely, by favorable (humid) conditions for fungi growth and spore production. As observed for pollen, Sporormiella concentration values remain low due to increased ice accumulation rates. The Sporormiella concentrations rise slightly after $1600 \mathrm{AD}$, which might be related to intensified herding activities over the past centuries.

\section{Diversity and ordination analysis}

In a large pollen catchment such as Tsambagarav that includes a wide range of habitats, 339 pollen richness is rather related to ecosystem diversity and thus the number of habitats, than to 340 floristic diversity within plant communities. Low PIE values $(<0.5)$ throughout the sequence 341 follow PRI suggesting that species evenness was constantly low. However, evenness 342 reconstructions were possibly affected by the large Artemisia portions, a pollen taxon that is 343 commonly overrepresented in steppic ecosystems (Liu et al., 1999) and prevails over the entire 344 record (Figs 2-3). PRI and DE-PRI remain low until 3000 BC (PRI ca. 5-15; DE-PRI ca. 10), 345 followed by an increase (PRI max. 20-30, DE-PRI 15) between 3000 and 2400 BC when AP 346 percentages are peaking. Given that pollen richness is correlated with AP $(r=0.64$, Figs $2-3)$ 347 it is likely that forest expansions contributed to increasing diversity. After the forest retreat at 3481800 BC, diversity remained at intermediate levels (PRI ca. 10-20, DE-PRI ca. 10-15) until 3491700 AD. Higher diversity in the younger steppes (pre-3000 BC vs. post-1800 BC) was possibly 350 related to reorganizations to grassy steppe communities (e.g. Poaceae increase; Fig. 3). 351 Palynological diversity drops to low values after 1700 AD (PRI and DE-PRI around 10) 
suggesting a further decline of diversity perhaps related to intensified herding (e.g.

353

354

355

356

357

358

359

360

361

362

363

364

365

366

367

368

Sporormiella rise).

The sample distribution on the PCA axes 1 and 2 (Fig. 4A) shows a large LPAZ overlap with only minor vegetation changes over the past five millennia. Samples of LPAZ TSA-1 and TSA-6 vs. TSA-4 are separated along axis 1 and samples of LPAZ TSA-2 and TSA-3a are shifted along axis 2, reflecting variations in the vegetation composition between different steppe communities and boreal forests over time. A very high share (66 \%) of the variance is explained by axis 1 which splits mainly moist steppe communities (Artemisia, Persicaria vivipara) from the rest: dry steppic (Chenopodiaceae, Rheum, Poaceae), cryophilous alpine Kobresia-meadow (e.g. Cyperaceae) and rather mesophilous boreal forests (e.g. Betula, Pinus sibirica). Axis 2 explains another $21 \%$ of the variance and separates dry grass steppe (e.g. Poaceae, Chenopodiaceae, Thalictrum) from cryophilous, mesophilous and rather thermophilous communities: tundra shrublands (e.g. Alnus viridis), boreal (Picea, Larix, Betula) and nemoboreal or temperate (e.g. Ulmus, Quercus, Corylus) arboreal taxa. Thus, both axes may indicate aspects related to moisture availability and associated temperatures, such as steppic species composition (e.g. Artemisia vs. Chenopodiaceae and Poaceae for axis 1) and biomass or biome allocation (steppic vs. boreal or nemoboreal) for axis 2.

PCA for the Belukha samples (Fig. 4B) reveals that the Tsambagarav results are reproducible in the Russian Altai. Axis 1 explains $42 \%$ of the variance separating Artemisia from dry steppic Stipa-communities (e.g. Poaceae, Chenopodiaceae) and axis 2 explains $22 \%$ separating dry steppes from boreal forests (Betula, Pinus sibirica). The compositional similarities between the two PCA suggests moisture availability and less important temperature as drivers of vegetation change. If combined (Fig. 4A) Russian Altai sample scores group in one edge of Axis 1, along an axis 2 gradient. The sample score comparison suggests a high similarity of Belukha with Tsambagarav during the afforestation phase 3000-1800 BC (TSA-2-TSA-3a). The ordination clearly separates modern Tsambagarav (TSA-6) and Belukha samples probably because of moisture-related differences and different anthropogenic influence on both, Mongolian and 

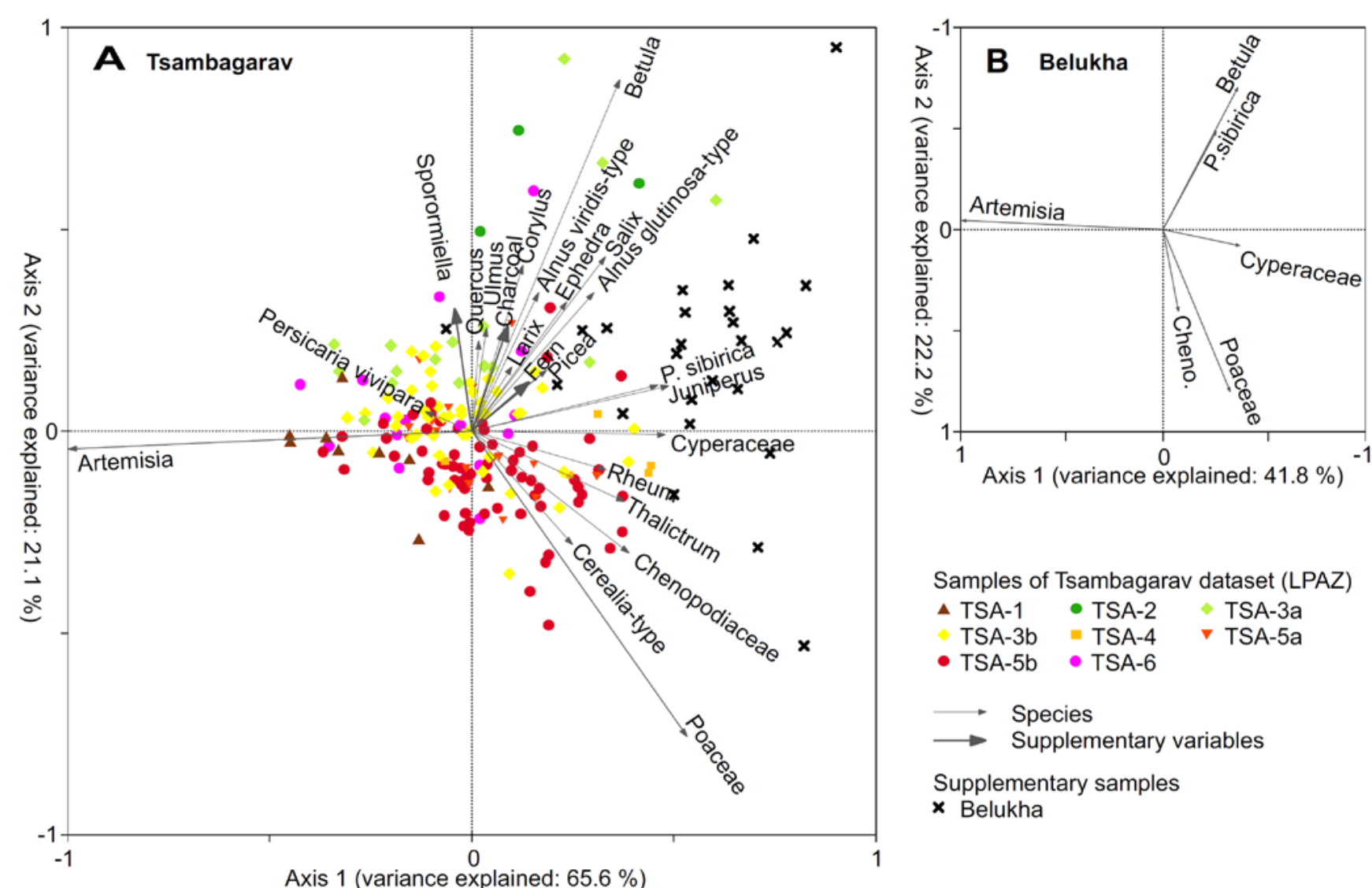

Axis 1 (variance explained: $65.6 \%$ )

Samples of Tsambagarav dataset (LPAZ)

$\begin{array}{lll}\text { TSA-1 } & - \text { TSA-2 } & \text { TSA-3a } \\ \text { TSA-3b } & =\text { TSA-4 } & \text { TSA-5a } \\ \text { - TSA-5b } & - \text { TSA-6 } & \end{array}$

$\longrightarrow$ Species

$\longrightarrow$ Supplementary variables

Supplementary samples

x Belukha

Figure 4 Principle component analysis (PCA) for pollen percentages of Altai glacier records. Panel A: PCA for the Mongolian Altai (Tsambagarav glacier) today surrounded by open steppes with only relict forest patches, spanning 3500 BC2009 AD. Sample scores with different symbols for the corresponding local pollen assemblage zone (LPAZ), selected species scores (black arrows corresponding to pollen types) indicate vegetation composition changes for sample scores from boreal forest (e.g. Pinus cembra) to less dry (e.g. Artemisia) and arid steppes (e.g. Chenopodiaceae). Selected supplementary variables (grey arrows, Sporormiella and fern spores as percentages of the terrestrial pollen sum [\%], charcoal concentrations [particles $\left.\mathrm{l}^{-1}\right]$ ). Russian Altai (Belukha glacier) today surrounded by abundant boreal forests spanning 1250-2001 AD. Sample scores are plotted as supplementary data not influencing the ordination (black cross symbols). The PCA results underline the similarity of mid-Holocene forest communities in the Mongolian Altai with historical and modern boreal forests in the Russian Altai. Panel B: Selected species scores for the Belukha dataset. Selected species scores for the Russian Altai show a close relationship with species scores from the Mongolian Altai (Panel A). Taken together this finding underscores the vulnerability of extant Central Asian forests to current and future climate change. Specifically, future vegetation dynamics in the Russian Altai may follow past climate impact trajectories in the Mongolian Altai, from forested (positive scores) to steppic communities (negative scores) along PCA axis 1. 
The average charcoal concentration in the upper firn (ca. 6000 particles $\mathrm{l}^{-1}$ for the period 2009-2005 AD) corresponds to a microscopic charcoal influx of ca. 200 particles $\mathrm{cm}^{-2}$ year $^{-1}$ or $0.085 \mathrm{~mm}^{2} \mathrm{~cm}^{-2}$ year-1 (Tinner \& Hu, 2003), which is extremely low if compared to sediment records (Adolf et al., 2017). Charcoal concentrations reveal no major fire activity trend between $3500 \mathrm{BC}$ and $1700 \mathrm{AD}$ with an average of $\sim 5000$ particles $\mathrm{l}^{-1}$. A single outstanding charcoal 401 peak around 1540 BC (29’000 particles $1^{-1}$ ) suggests a short phase of major fire activity ca. 250 402 years after a major forest decline. Other charcoal-concentration inferred fire-activity peaks ( $>90$-percentile $=>7300$ particles $\mathrm{l}^{-1}$; Figs $\left.2-3\right)$ also occurred following forest declines (e.g. 2650 BC ca. 150 years after the forest decline around 2800 BC), suggesting that collapses of boreal taxa provided dead biomass and thus fuel for fire activity (De Groot et al., 2000; Eichler 406 et al., 2011; Tinner et al., 2015; Kuuluvainen et al., 2017). Charcoal concentrations remain low 407 after $1700 \mathrm{AD}$ with an average of $\sim 2600$ particles $\mathrm{l}^{-1}$ and no peaks $>90$-percentile indicating minimal fire activity when herbaceous steppe ecosystems were dominant. However, microscopic charcoal hints to minor increase of fire activity after 1960 AD. Charcoal concentration as supplementary variable in the PCA (Fig. 4) groups with AP, again suggesting biomass availability as an important factor for burning.

First SCP occur around ca. $1720 \mathrm{AD}$ at the beginning of zone TSA-5b (Fig. 3). Those scattered but frequent particles indicate initial atmospheric pollution, possibly deriving from early industrialization and mining activities (Naumov, 2006). Regionally, they coincide with 415 minimum fire activity and maximum landscape openness, indicating a possible shift from solely 416 timber-based to increasingly fossil fuel-based energy consumption, perhaps motivated by 417 limited timber availability. SCP rise after 1920 AD, suggesting amplified industrial air pollution 418 during the $20^{\text {th }}$ century. A first concentration peak around $1960 \mathrm{AD}$ with 80 particles $\mathrm{l}^{-1}$ and a 419 second maximum around 2000 AD (100 particles $\mathrm{l}^{-1}$ ) coincide with highest charcoal 420 concentration values (6000 particles $\mathrm{l}^{-1}$ ) during the $20^{\text {th }}$ century. 


\section{DISCUSSION}

422

423

424

425

426

427

428

429

430

431

432

433

434

435

436

437

438

439

440

441

442

443

444

445

446

\section{Fire and fuel dynamics during the past 5000 years}

Tsambagarav receives ca. 200 microscopic charcoal particles $\mathrm{cm}^{-2} \mathrm{yr}^{-1}$ today which is in the same order of magnitude as Belukha glacier $320 \mathrm{~km}$ northwest in the Russian Altai (150 particles $\mathrm{cm}^{-2} \mathrm{yr}^{-1}$; Eichler et al., 2011) at a similar altitude (4062 m a.s.l.). Charcoal influx values at Belukha are ca. 40 times lower than at nearby Teletskoye Lake at $1900 \mathrm{~m}$ a.s.l. (8200 particles $\mathrm{cm}^{-2} \mathrm{yr}^{-1}$; Andreev et al., 2007). The influx difference between glaciers and neighboring lake sediment archives is best explained by the remoteness of the glaciers and the limited vertical atmospheric transport to the high elevation ice core sites (Gilgen et al., in review). To our knowledge, no microscopic charcoal records from the Mongolian Altai are available. Local fire reconstructions are based on macroscopic charcoal and cover the past millennia (Umbanhowar et al., 2009; Unkelbach et al., 2018). Despite the spatio-temporal variability their reconstructed fire signal corresponds to our regional fire activity peaks from Tsambagarav (microscopic charcoal peaks >90-percentile, Fig. A1), if dating uncertainties are considered. Recent calibration studies at the continental scale showed that micro- and macroscopic charcoal has very similar spatial proveniences spanning a radius of about $40 \mathrm{~km}$ around sedimentary sites (Adolf et al., 2017). Glaciers on the other hand act as a regional to subcontinental archive of biomass burning, integrating fire activity over larger spatial scales (Legrand et al., 2016). Very high concentrations $>20.000$ particles $\mathrm{l}^{-1}$ suggest that the fire activity peak in the Tsambagarav record around 1500 BC was comparable to the maximum burning of the past 800 years that occurred around $1600 \mathrm{AD}$ at Belukha glacier in the Russian Altai (Fig. A2). The 1500 BC maximum fire phase in the Tsambagarav record may chronologically correspond to the late-Holocene fire activity peak at Zagas Nur around $20 \mathrm{~km}$ southwest of Tsambagarav (Umbanhowar et al., 2009) where it is dated to 1400 BC, while at Doroo Nur (50 km south) fire activity was only moderate around 1500 BC. As the fire peak does not occur in more distant records from western Mongolia (Fig. A1; Umbanhowar et al., 
448 located north or northwest.

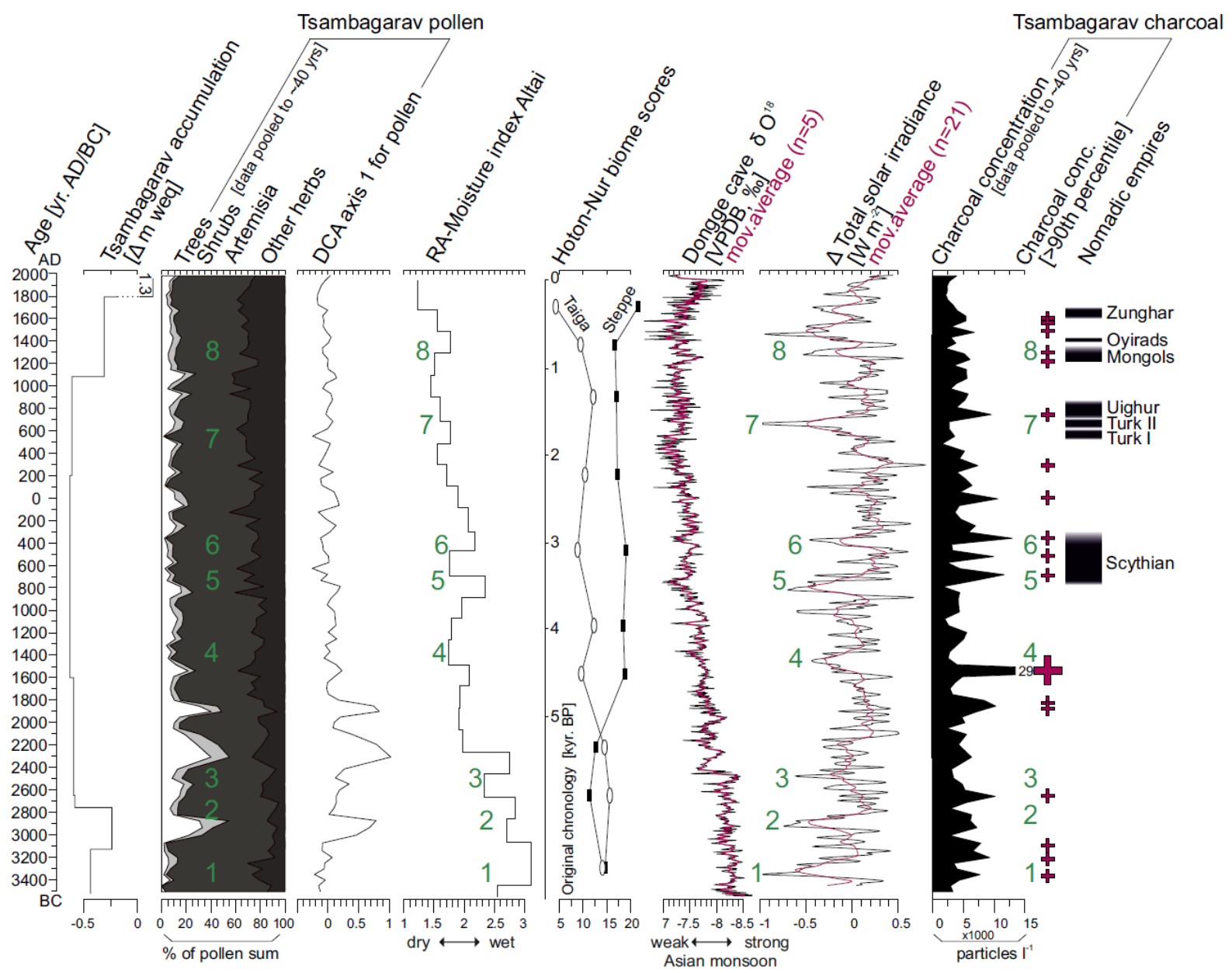

450

451

452

453

454

455

456

457

458

459

Figure 5 Comparison of the palynological record from Tsambagarav with regional and climate records. From left: Tsambagarav ice accumulation rate (anomaly from the mean of the past 6000 years, Herren et al., 2013), Tsambagarav vegetation reconstruction (summary curve for pollen, DCA-axis 1, correlation arboreal pollen percentages : DCA scores axis 1: $\mathrm{r}=0.95$; this study), regionally-averaged moisture index for the Altai Mountains based on pollen records (Wang \& Feng, 2013), biome scores from Hoton Nur with original chronology adjusted (Tarasov et al., 2000; Rudaya et al., 2009), Asian monsoon reconstruction from Dongge cave (Wang et al., 2005), solar activity fluctuation reconstruction based on ${ }^{10} \mathrm{Be}$ measurements in polar ice (Steinhilber et al., 2009), Tsambagarav fire reconstruction (charcoal concentrations, this study) and selected nomadic empires (Rogers, 2012). Green numbers indicate climatically induced forest minima phases at Tsambagarav.

Increased fire activity at Tsambagarav was related to declines of boreal tree stands or forests that likely provided fuel for burning (Fig. 5), similarly to what was found at Belukha (Eichler et al., 2011). There, a dry period inducing forest diebacks was succeeded by maximum fire activity around $1600 \mathrm{AD}$ (Fig. A2), a period with increased fire activity also in the Tsambagarav area (three consecutive charcoal peaks >90-percentile; Fig. 5) and in the Eurasian Arctic (Akademii Nauk ice record; Griemann et al., 2017). Lacking biomass availability combined with low temperatures during the Little Ice Age period may explain the fire minimum at 1700- 
$1960 \mathrm{AD}$ when maximum vegetation openness is documented in the pollen record of

Tsambagarav and at adjacent sites (Fig. 5; Umbanhowar et al., 2009, Unkelbach et al., 2018).

Finally, the past four decades of the Tsambagarav record suggest again a slight increase of regional and local fire activity possibly caused by increased biomass availability due to pioneer birch forest expansions.

\section{Composition, successional dynamics and diebacks of the mid-Holocene forests}

Our high-resolution record from Tsambagarav provides a unique chronological control in combination with high-temporal and continuous sampling resolution and is therefore suited to assess rapid ecosystem responses to climate change. The Tsambagarav record suggests that the Mongolian Altai experienced several prominent forest contraction and expansion phases before 1800 BC. The magnitude and fluctuation pattern of this early phase are comparable to the pattern observed for the past 800 years in the Russian Altai (Eichler et al., 2011). There, mixed Pinus sibirica-Larix sibirica stands form a dense forest belt between $1000 \mathrm{~m}$ a.s.l. and the timberline around $2000 \mathrm{~m}$ a.s.l. in which Abies sibirica and Picea obovata co-occur in areas where soil moisture is sufficient (Eichler et al., 2011). Below this belt Betula pendula and Pinus sylvestris form boreal forests (Walter, 1974). The forests in the Russian Altai produce a pollen signal which is comparable to that of the Tsambagarav record during the period 3000-1800 BC (Figs 4 and A2). The Belukha pollen assemblage is mainly composed of Pinus sibirica and Betula with only single Larix grains despite its importance in the vegetation (Eichler et al., 2011). Scattered Larix pollen in the Tsambagarav record may thus suggest that Larix sibirica was an important forest element during the afforestation phases in the Mongolian Altai. This similarity is striking, given that nowadays Larix sibirica and Pinus sibirica form only relict and discontinuous forest belts in the northern part of the Mongolian Altai and Abies sibirica has completely vanished (Walter, 1974; Gunin et al., 2009).

The multiproxy Belukha record suggests that forest diebacks in the Russian Altai were induced by severe drought decades resulting in enhanced fire risk and that forests recovered 
492

493

494

495

496

497

498

499

500

501

502

503

504

505

506

507

508

509

510

511

512

513

514

515

516

517

rapidly after moisture re-increased (Eichler et al., 2011). The repeated forest contractions at Tsambagarav followed by Artemisia steppe expansions indicate similar vegetation responses to moisture variability. Forest recoveries similar to the Russian Altai ended 1800 BC. This is in line with regional sedimentary pollen records showing consistent deforestation in the Mongolian Altai during the mid- to late-Holocene. For instance, pollen-inferred vegetation reconstructions from Hoton Nur point to taiga forest contractions between 3000-2000 BC (Fig. 5; Rudaya et al., 2009) to never recover again. At Bayan Nur forests contracted around 1500 BC, in the Dayan Nur region around 650 BC and in the Achit Nur area between 4000 BC and 200 AD (Gunin et al., 2009; Sun et al., 2013; Unkelbach et al., 2018). Diachronic forest diebacks suggest that moisture thresholds for forest growth were underrun in different periods in the Mongolian Altai. Specifically, local forest persistence until about 800 BC, 1200 AD and $1700 \mathrm{AD}$ indicates that decreasing moisture effects on forests endured until modern times, resulting in stepwise forest and tree stand disruptions. These late-Holocene dynamics occurred also at larger distances, e.g. at Akkol Lake (ca. 190 km) in the northern Tuva region after 1000 BC (Blyakharchuk et al., 2004; Fig. 1A) suggesting that forests contracted also far north of the Mongolian Altai in response to moisture reductions. However, chronological uncertainties as resulting from few ${ }^{14} \mathrm{C}$-dates from bulk sediments (see Rey et al., 2018) and a general lack of ${ }^{14} \mathrm{C}$-dates in the mid- to late-Holocene (Gunin et al., 2009; Sun et al., 2013) impede precise assessments of the deforestation timing at individual sites.

\section{Climate-driven pulses of steppe expansions and human impact after $1800 \mathrm{BC}$}

Hunter and gatherer communities inhabited the Altai region since the early-Holocene (Volkov, 1995; Hauck et al., 2012), and nomadic herders were present since at least 1000 BC (Fig. 5; Fernández-Giménez, 1999; Rogers, 2012; Rudaya et al., 2008), but their impact on the natural vegetation is supposed to be minor (Bourgeois et al., 2007; Rudaya et al., 2009). We thus assume that natural climate change, such as aridity and/or cooling, was the main forcing of repeated forest contractions and subsequent herbaceous steppes expansions during the late- 
Holocene (Schlütz et al., 2008). A pollen-based moisture index derived from other sites in the Mongolian Altai (Wang \& Feng, 2013) was previously interpreted as a proxy for the Asian summer monsoon strength (Fig. 5). This index is driven by the same factors as our pollen data and is therefore not an independent climatic proxy and indeed its course is in line with our ecological interpretation, thus indicating similar moisture trends across sites. The vegetationbased reconstructions are in good agreement with mid-Holocene climate model simulations for Asian monsoon strength (Harrison et al., 2016) and with pollen-independent oxygen isotope records (e.g. Dongge cave record; Fig. 5; Wang et al., 2005; Wang \& Feng, 2013) that suggest declining moisture availability in the Mongolian Altai in response to a weakening of monsoon activity resulting from changes of orbital forcing during the late-Holocene. Reduced monsoon sources of moisture as a possible cause for deforestation at Hoton Nur was proposed by Rudaya et al. (2009). Although our Tsambagarav vegetation and fire record begins at $3500 \mathrm{BC}$ when monsoon had already started to weaken (Wang et al., 2005), we assume that the progressive late-Holocene reduction of subtropical air-masses resulted in strong moisture oscillations that may have resulted in flickering of forest ecosystems before their final collapse at ca. 1800 BC (Dakos et al., 2013).

The Tsambagarav record suggests that the long-term tree contraction in the Mongolian Altai continued stepwise after 1800 BC to reach its apex only 300-200 years ago. Contractions of forest ecosystems were possibly induced by climate variability related to e.g. solar activity changes (Eichler et al., 2009; Steinhilber et al., 2009; Roth \& Joos, 2013). For instance, the forest minima around 3400 BC, 2800 BC, 2500 BC, 800-400 BC, 500 AD, and 1200 AD might have been related to dry cooling events (Fig. 5) as partly recorded regionally (e.g. the $4.2 \mathrm{kyr}$ cool and dry period, Staubwasser \& Weiss, 2006; Dixit et al., 2014), in other Northern Hemisphere records from the Alpine region and Alaska (Haas et al., 1998; Tinner et al., 2015) or in the reconstructed global surface air temperature (Roth \& Joos, 2013).

43 During the past decades, climate proxies suggest reversing climate trends with warming (e.g. Eichler et al., 2009; Roth \& Joos, 2013) and re-strengthening of the Asian monsoon (e.g. 
reconstructed from Dongge cave isotope record; Wang et al., 2005). In contrast, after the end

546

of the Little Ice Age at ca. 1850 AD (Eichler et al., 2011) tree stands in the Mongolian Altai did not recover suggesting a decoupling of vegetation dynamics from climate, e.g. due to increasing human activities. The historical onset of larger-scale smelting in the Altai dates to 1729 AD (Naumov, 2006) coinciding with the beginning of the industrial pollution signal in our ice record as documented in SCPs (Fig. 3). The related energy requirements induced increasing human pressure not only on the Russian Altai forests but also on the remaining tree stands in the Mongolian Altai until 1960 AD (Lkhagvadorj et al., 2013), likely shifting the lower tree line upwards (Dulamsuren et al., 2014). Thus, human activities altered vegetation responses to climate. The Tsambagarav record suggests that industrial pollution remained high after 1960 $\mathrm{AD}$ and only pioneer Betula pendula may have very recently recovered, when fossil fuel-based energy consumption (e.g. coal or diesel-consuming engines for heating, transportation or watersupply) increased, relieving pressure on woody stands (Fernández-Giménez, 1999).

\section{Altai ecosystems under future climate change}

Past vegetation dynamics suggest that warmer and moister conditions during the midHolocene allowed boreal forest establishments in the Tsambagarav area in the Mongolian Altai. These forests collapsed around 1800 BC. Subsequently, further stepwise tree reductions and a gradual shift to more dry adapted steppe communities occurred likely in response to drying and cooling during the late-Holocene. Future climate projections for continental areas propose further warming and drying in the coming decades for the Altai Region (Sato, Kimura, \& Kitoh, 2007; Tchebakova, Blyakharchuk, \& Parfenova, 2009; Dai, 2011; Collins et al., 2013; Dulamsuren, Khishigjargal, Leuschner, \& Hauck, 2014; IPCC, 2014; Lehner et al., 2017). In agreement, during the past decades, the Mongolian Altai experienced significant warming and increasing numbers of drought periods. Precipitation more often included heavy rainfall events that are only partly beneficial for vegetation (D'Arrigo et al., 2001; Dulamsuren, Hauck, \& Leuschner 2010; Lkhagvadorj, Hauck, Dulamsuren, \& Tsogtbaatar, 2013). Other areas in 
Mongolia and southern Siberia also experienced climate warming and moisture decrease,

572 probably affecting tree growth and hindering forest regeneration (Allen et al., 2010;

573 Tsogtbaatar, 2013; Dulamsuren, Khishigjargal, Leuschner, \& Hauck, 2014; Xu et al., 2017). If

574 future climate projections are correct about declining moisture availability, the persisting forest

575 patches and belts in the Mongolian, Russian Altai and other dry areas of Central Asia will be

576 strongly affected. For instance, forest boundaries might shift north of the Russian Altai

577 releasing unprecedented forest collapses in response to increasing drought. The available fire

578 histories from ice core records from the Russian and Mongolian Altai also suggest that fire

579 incidence may increase where biomass is not limiting burning (Eichler et al., 2011; Hessl et al.,

580 2016). This interpretation of the paleo record agrees with modern observations indicating a

581 significant link between dry conditions and fire activity (Tsogtbaatar, 2013; Ponomarev \&

582 Kharuk, 2016). Thus, fire may exacerbate the effects of future climate change on vegetation,

583 especially if associated to high grazing pressure (Tsogtbaatar, 2004; Hauck et al., 2014;

584 Ponomarev \& Kharuk, 2016).

585 In the past, when climate forcing was natural, warm conditions were in this region usually

586 accompanied by increases in moisture availability, likely deriving from increased monsoonal

587 and/or westerly wind activity that promoted forest growth. Despite many projection efforts and

588 progresses, the magnitude of global warming and in particular of precipitation changes remains

589 ambiguous (Braconnot et al., 2012). Future projections may underestimate moisture availability

590 in continental areas (Berg, Sheffield, \& Milly, 2017), as for example, northern hemisphere

591 monsoon simulations for the mid-Holocene underestimate its magnitude (Braconnot et al.,

592 2012; Harrison et al., 2015). If moisture should unexpectedly increase with future warming as

593 it did during the early and mid late-Holocene, forests may thus persist and perhaps even expand

594 in the Mongolian Altai, as they did during the period 3000-1800 BC, at least if human pressure

595 will not become excessive. 


\section{CONCLUSIONS}

597

598

599

600

601

602

603

604 605

606

607

608

609

610

611

612

613

614

615

616

617

618

619

The Tsambagarav record demonstrates for the first time the ecological potential of ice palynology, specifically, based on its high chronological resolution and precision, it provides novel insights into past fire, vegetation, and land use dynamics in the Mongolian Altai region. Late-Holocene vegetation reorganizations in response to climate and moisture availability changes underscore the vulnerability of forest ecosystems that are still thriving in the Mongolian or Russian Altai. We conclude that precipitation regime changes were the main driver for forest diebacks ca. 4700-4000 years ago and their final collapse ca. 3800 years ago. The lacking resilience of forest communities (e.g. Pinus sibirica-Larix sibirica stands) to moisture changes emphasizes the vulnerability of forests in other dry areas of Central Asia, if global warming will be associated to moisture declines as anticipated by future scenarios (IPCC, 2014). To better assess past vegetation and forest fire dynamics, new high-resolution and precision multiproxy studies from natural archives are urgently needed. Such studies may help to disclose the mechanisms and processes behind the vulnerability of plant species and communities. Ultimately, they are thus essential to improve our knowledge of future ecosystem responses to global change.

\section{ACKNOWLEDGMENTS}

We are grateful to Ch.E. Umbanhowar for providing macroscopic charcoal data, to J.F.N. van Leeuwen for assistance with rare pollen type analysis, to J. Unkelbach from University of Göttingen for valuable discussions, to the Russian Federation for support with the international drilling campaign, and to the ice drilling crew. We thank H. Behling and an anonymous reviewer for constructive remarks that substantially improved the manuscript. We acknowledge the Sinergia project Paleo fires from high-alpine ice cores funded by the Swiss National Science Foundation (SNF grant 154450). 
All data will be deposited in the Alpine Palynological Database (ALPADABA) and the

Neotoma database (www.neotomadb.org).

\section{REFERENCES}

Adolf, C., Wunderle, C., Colombaroli, C., Weber, H., Gobet, E., Heiri, O., van Leeuwen, J. F. N., Bigler, C., Connor, S. E., Gałka, M., La Mantia, T., Makhortykh, S., SvitavskáSvobodová, H., Vannière, B., \& Tinner, W. (2017). The sedimentary and remote-sensing reflection of biomass burning in Europe. Global Ecology and Biogeography, 27, 199-212. https://doi.org/10.1111/geb.12682

Allen, C. D., Macalady, A. K., Chenchouni, H., Bachelet, D., McDowell, N., Vennetier, M., Kitzberger, T., Rigling, A., Breshears, D. D., Hogg, E. H., Gonzalez, P., Fensham, R., Zhang, Z., Castro, J., Demidova, N., Lim, J.-H., Allard, G., Running, S. W., Semerci, A., \& Cobb, N. (2010). A global overview of drought and heat-induced tree mortality reveals emerging climate change risks for forests. Forest ecology and management, 259(4), 660-684. https://doi.org/10.1016/j.foreco.2009.09.001

Andreev, A. A., Pierau, R., Kalugin, I. A., Daryin, A. V., Smolyaninova, L. G., \& Diekmann, B. (2007). Environmental changes in the northern Altai during the last millennium documented in Lake Teletskoye pollen record. Quaternary Research, 67(3), 394-399. https://doi.org/10.1016/j.yqres.2006.11.004

Beer, R., Heiri, O., \& Tinner, W. (2007). Vegetation history, fire history and lake development recorded for 6300 years by pollen, charcoal, loss on ignition and chironomids at a small lake in southern Kyrgyzstan (Alay Range, Central Asia). The Holocene, 17(7), 977-985. https://doi.org/10.1177/0959683607082413

Bennett, K. D. (1996). Determination of the number of zones in a biostratigraphical sequence. New Phytologist, 132(1), 155-170. https://doi.org/10.1111/j.1469-8137.1996.tb04521.x

Berg, A., Sheffield, J., \& Milly, P. C. (2017). Divergent surface and total soil moisture projections under global warming. Geophysical Research Letters, 44(1), 236-244. https://doi.org/10.1002/2016GL071921

Beug, H.-J. (2004). 2004: Leitfaden der Pollenbestimmung für Mitteleuropa und angrenzende Gebiete. Munich: Pfeil.

Birks, H.-J. (1968). The identification of Betula nana pollen. New Phytologist, 67(2), 309-314. https://doi.org/10.1111/j.1469-8137.1968.tb06386.x

Birks, H. J. B., \& Gordon, A. (1985). Numerical Methods in Quaternary Pollen Analysis. London: Academic Press.

Birks, H. J. B., \& Line, J. M. (1992). The use of rarefaction analysis for estimating palynological richness from Quaternary pollen-analytical data. The Holocene, 2(1), 1-10. https://doi.org/10.1177/095968369200200101

Blyakharchuk, T. A., Wright, H. E., Borodavko, P. S., van der Knaap, W. O., \& Ammann, B. (2004). Late Glacial and Holocene vegetational changes on the Ulagan high-mountain 
Bourgeois, J., De Wulf, A., Goossens, R., \& Gheyle, W. (2007). Saving the frozen scythian tombs of the altai mountains (Central Asia). World Archaeology, 39(3), 458-474.

663

664

665

666

667

668

Braconnot, P., Harrison, S. P., Kageyama, M., Bartlein, P. J., Masson-Delmotte, V., Abe-Ouchi, A., Otto-Bliesner, B., \& Zhao, Y. (2012). Evaluation of climate models using palaeoclimatic data. Nature Climate Change, 2(6), 417. doi:10.1038/nclimate1456

Brugger, S. O., Gobet, E., Schanz, F., Heiri, O., Schwörer, C., Sigl, M., Schwikowski, M., \& Tinner, W. (2018). A quantitative comparison of microfossil extraction methods from ice cores. Journal of glaciology, 64(245), 432-442. https://doi.org/10.1017/jog.2018.31

Clegg, B. F., Tinner, W., Gavin, D. G., \& Hu, F. S. (2005). Morphological differentiation of Betula (birch) pollen in northwest North America and its palaeoecological application. The Holocene, 15(2), 229-237. https://doi.org/10.1191/0959683605hl788rp

Collins, M., R. Knutti, J. Arblaster, J.-L. Dufresne, T. Fichefet, P. Friedlingstein, X. et al. (2013). Long-term Climate Change: Projections, Commitments and Irreversibility. In: Climate Change 2013: The Physical Science Basis. Contribution of Working Group I to the Fifth Assessment Report of the Intergovernmental Panel on Climate Change [Stocker, T.F., D. Qin, G.-K. Plattner, M. Tignor, S.K. Allen, J. Boschung, A. et al. (eds.)]. Cambridge University Press, Cambridge, United Kingdom and New York, NY, USA.

Colombaroli, D., \& Tinner, W. (2013). Determining the long-term changes in biodiversity and provisioning services along a transect from Central Europe to the Mediterranean. The Holocene, 23(11), 1625-1634. https://doi.org/10.1177/0959683613496290

Conedera, M., Tinner, W., Neff, C., Meurer, M., Dickens, A. F., \& Krebs, P. (2009). Reconstructing past fire regimes: methods, applications, and relevance to fire management and conservation. Quaternary Science Reviews, 28(5), 555-576. https://doi.org/10.1016/j.quascirev.2008.11.005

Dai, A. (2011). Drought under global warming: a review. Wiley Interdisciplinary Reviews: Climate Change, 2(1), 45-65. https://doi.org/10.1002/wcc.81

Dakos, V., van Nes, E. H., \& Scheffer, M. (2013). Flickering as an early warning signal. Theoretical Ecology, 6(3), 309-317. https://doi.org/10.1007/s12080-013-0186-4

D'Arrigo, R., Jacoby, G., Frank, D., Pederson, N., Cook, E., Buckley, B., Nachin, B., Mijiddorj, R., \& Dugarjav, C. (2001). 1738 years of Mongolian temperature variability inferred from a tree-ring width chronology of Siberian pine. Geophysical Research Letters, 28(3), 543-546. https://doi.org/10.1029/2000GL011845

De Groot R. C., Woodward B., \& Hennon P. E. (2000). Natural decay resistance of heartwood from dead, standing yellow-cedar trees: laboratory evaluations. Forest Product Journal 50, 53-59.

Dixit, Y., Hodell, D. A., \& Petrie, C. A. (2014). Abrupt weakening of the summer monsoon in northwest India 4100 yr ago. Geology, 42(4), 339-342 https://doi.org/10.1130/G35236.1

Dulamsuren, C., Hauck, M., \& Leuschner, C. (2010). Recent drought stress leads to growth reductions in Larix sibirica in the western Khentey, Mongolia. Global Change Biology, 16(11), 3024-3035. https://doi.org/10.1111/j.1365-2486.2009.02147.x 
Dulamsuren, C., Klinge, M., Degener, J., Khishigjargal, M., Chenlemuge, T., BatEnerel, B., Yeruult, Y., Saindovdon, D., Ganbaatar, K., Tsogtbaatar, J., Leuschner, C., \& Hauck, M. (2016). Carbon pool densities and a first estimate of the total carbon pool in the Mongolian forest-steppe. Global change biology, 22(2), 830-844. https://doi.org/10.1111/gcb.13127

Dulamsuren, C., Khishigjargal, M., Leuschner, C., \& Hauck, M. (2014). Response of tree-ring width to climate warming and selective logging in larch forests of the Mongolian Altai. Journal of Plant Ecology, 7(1), 24-38. https://doi.org/10.1093/jpe/rtt019

Eichler, A., Tinner, W., Brütsch, S., Olivier, S., Papina, T., \& Schwikowski, M. (2011). An icecore based history of Siberian forest fires since AD 1250. Quaternary Science Reviews, 30(9), 1027-1034. https://doi.org/10.1016/j.quascirev.2011.02.007

Eichler, A., Olivier, S., Henderson, K., Laube, A., Beer, J., Papina, T., Gäggeler, H. W., \& Schwikowski, M. (2009). Temperature response in the Altai region lags solar forcing. Geophysical Research Letters, 36(1). https://doi.org/10.1029/2008GL035930

Fernández-Giménez, M. E. (1999). Sustaining the steppes: a geographical history of pastoral land use in Mongolia. Geographical Review, 89(3), 315-342. https://doi.org/10.2307/216154

Finsinger, W., \& Tinner, W. (2005). Minimum count sums for charcoal concentration estimates in pollen slides: accuracy and potential errors. The Holocene, 15(2), 293-297. https://doi.org/10.1191/0959683605hl808rr

Gilgen, A., Adolf, C., Brugger, S. O., Ickes, L., Schwikowski, M., van Leeuwen, J. F. N., Tinner, W., \& Lohmann, U. (in review). Implementing Microscopic Charcoal Particles into a Global Aerosol-Climate Model. https://doi.org/10.5194/acp-2017-1116

Golan-Goldhirsh, A. (2009). Bridging the gap between ethnobotany and biotechnology of Pistacia. Israel journal of plant sciences, 57(1-2), 65-78.

Grieman, M. M., Aydin, M., Fritzsche, D., McConnell, J. R., Opel, T., Sigl, M., \& Saltzman, E. S. (2017). Aromatic acids in a Eurasian Arctic ice core: a 2600-year proxy record of biomass burning. Climate of the Past, 13(4), 395. https://doi.org/10.5194/cp-13-395-2017

Gunin, P. D., Vostokova, E. A., Dorofeyuk, N. I., Tarasov, P. E., \& Black, C. C. (Eds.). (1999). Vegetation Dynamics of Mongolia. Dordrecht: Kluwer Academic Publishers.

Haas, J. N., Richoz, I., Tinner, W., \& Wick, L. (1998). Synchronous Holocene climatic oscillations recorded on the Swiss Plateau and at timberline in the Alps. The Holocene, 8(3), 301-309. https://doi.org/10.1177/0959683607082413

Harrison, S. P., Bartlein, P. J., \& Prentice, I. C. (2016). What have we learnt from palaeoclimate simulations?. Journal of Quaternary Science, 31(4), 363-385. https://doi.org/10.1002/jqs.2842

Harrison, S. P., Bartlein, P. J., Izumi, K., Li, G., Annan, J., Hargreaves, J., Braconnot, P., \& Kageyama, M. (2015). Evaluation of CMIP5 palaeo-simulations to improve climate projections. Nature Climate Change, 5(8), 735. https://doi.org/10.1038/nclimate2649

Hauck, M., Dulamsuren, C., Bayartogtokh, B., Ulykpan, K., Burkitbaeva, U. D., Otgonjargal, E., Titov, S. V., Enkhbayar, T., Sundetpaev, A. K., Beket, U., \& Leuschner, C. (2014). Relationships between the diversity patterns of vascular plants, lichens and invertebrates in the Central Asian forest-steppe ecotone. Biodiversity and conservation, 23(5), 1105-1117. https://doi.org/10.1007/s10531-014-0648-z 
Hauck, M., Javkhlan, S., Lkhagvadorj, D., Bayartogtokh, B., Dulamsuren, C., \& Leuschner, C. (2012). Edge and land-use effects on epiphytic lichen diversity in the forest-steppe ecotone of the Mongolian Altai. Flora-Morphology, Distribution, Functional Ecology of Plants, 207(6), 450-458. https://doi.org/10.1016/j.flora.2012.03.008

Heiri, O., \& Lotter, A. F. (2001). Effect of low count sums on quantitative environmental reconstructions: an example using subfossil chironomids. Journal of Paleolimnology, 26(3), 343-350. https://doi.org/10.1023/A:1017568913302

Henne, P. D., Elkin, C. M., Reineking, B., Bugmann, H., \& Tinner, W. (2011). Did soil development limit spruce (Picea abies) expansion in the Central Alps during the Holocene? Testing a palaeobotanical hypothesis with a dynamic landscape model. Journal of Biogeography, 38(5), 933-949. https://doi.org/10.1111/j.1365-2699.2010.02460.x

Herren, P. A., Eichler, A., Machguth, H., Papina, T., Tobler, L., Zapf, A., \& Schwikowski, M. (2013). The onset of Neoglaciation 6000 years ago in western Mongolia revealed by an ice core from the Tsambagarav mountain range. Quaternary Science Reviews, 69, 59-68. https://doi.org/10.1016/j.quascirev.2013.02.025

Hessl, A. E., Brown, P., Byambasuren, O., Cockrell, S., Leland, C., Cook, E., Nachin, B., Pederson, N., Saladyga, T., \& Suran, B. (2016). Fire and climate in Mongolia (1532-2010 Common Era). Geophysical Research Letters, 43(12), 6519-6527. https://doi.org/10.1002/2016GL069059

Hijioka, Y., E. Lin, J.J. Pereira, R.T. Corlett, X. Cui, G.E. Insarov, R.D. et al. (2014). Asia. In: Climate Change 2014: Impacts, Adaptation, and Vulnerability. Part B: Regional Aspects. Contribution of Working Group II to the Fifth Assessment Report of the Intergovernmental Panel on Climate Change [Barros, V.R., C.B. Field, D.J. Dokken, M.D. Mastrandrea, K.J. Mach, T.E. Bilir, M. et al. (eds.)]. United Kingdom and New York, NY: Cambridge University Press, Cambridge.

Huang, T. C. (1972). Pollen flora of Taiwan. Taipei: National Taiwan University, Botany Dept. Press.

Hurlbert, S. H. (1971). The nonconcept of species diversity: a critique and alternative parameters. Ecology, 52(4), 577-586. https://doi.org/10.2307/1934145

IPCC (2014). Climate Change 2014: Synthesis Report. Contribution of Working Groups I, II and III to the Fifth Assessment Report of the Intergovernmental Panel on Climate Change [Core Writing Team, R.K. Pachauri and L.A. Meyer (eds.)]. IPCC, Geneva, Switzerland, $151 \mathrm{pp}$.

Khansaritoreh, E., Dulamsuren, C., Klinge, M., Ariunbaatar, T., BatEnerel, B., Batsaikhan, G., Ganbaatar, K., Saindovdon, D., Yeruult, Y., Tsogtbaatar, J., Tuya, D., Leuschner, C., \& Markus Hauck, M. (2017). Higher climate warming sensitivity of Sibirian larch in small than large forest islands in the fragmented Mongolian forest steppe. Global change biology, 23, 3675-3689. https://doi.org/10.1111/gcb.13750

Klinge, M., Böhner, J., \& Lehmkuhl, F. (2003). Climate Pattern, Snow-and Timberlines in the Altai Mountains, Central Asia (Klimaverhältnisse, Schnee-und Waldgrenzen im Altai Gebirge, Zentralasien). Bonn: Erdkunde.

Kuuluvainen, T., Aakala, T., \& Várkonyi, G. (2017). Dead standing pine trees in a boreal forest landscape in the Kalevala National Park, northern Fennoscandia: amount, population 
Lang, G. (1994). Quartäre Vegetationsgeschichte Europas: Methoden und Ergebnisse. Jena, Stuttgart, New York: Gustav Fischer.

790

791

792

793

794

795

796

797

798

799

800

801

802

803

804

805

806

807

808

809

810

811

812

813

814

815

816

817

818

819

820

821

822

823

824

825

826

Legrand, M., McConnell, J., Fischer, H., Wolff, E. W., Preunkert, S., Arienzo, M., Chellman, N., Leuenberger, D., Maselli, O., Place, P., Sigl, M., Schüpbach, S., \& Flannigan, M. (2016). Boreal fire records in Northern Hemisphere ice cores: a review. Climate of the Past, 12(10), 2033-2059. https://doi.org/10.5194/cp-12-2033-2016

Lehner, F., Coats, S., Stocker, T. F., Pendergrass, A. G., Sanderson, B. M., Raible, C. C., \& Smerdon, J. E. (2017). Projected drought risk in $1.5^{\circ} \mathrm{C}$ and $2^{\circ} \mathrm{C}$ warmer climates. Geophysical Research Letters, 44(14), 7419-7428. https://doi.org/10.1002/2017GL074117

Lkhagvadorj, D., Hauck, M., Dulamsuren, C., \& Tsogtbaatar, J. (2013). Pastoral nomadism in the forest-steppe of the Mongolian Altai under a changing economy and a warming climate. Journal of arid environments, 88, 82-89. https://doi.org/10.1016/j.jaridenv.2012.07.019

Liu, H., Cui, H., Pott, R., \& Speier, M. (1999). The surface pollen of the woodland-steppe ecotone in southeastern Inner Mongolia, China. Review of Palaeobotany and Palynology, 105(3), 237-250. https://doi.org/10.1016/S0034-6667(98)00074-8

Liu, H., Park Williams, A., Allen, C. D., Guo, D., Wu, X., Anenkhonov, O. A., Liang, E., Sandanov, D. V., Yin, Y., Qi, Z., B \& Badmaeva, N. K. (2013). Rapid warming accelerates tree growth decline in semi-arid forests of Inner Asia. Global change biology, 19(8), 25002510. https://doi.org/10.1111/gcb.12217

McDowell, N. G., \& Allen, C. D. (2015). Darcy's law predicts widespread forest mortality under climate warming. Nature Climate Change, 5(7), 669. https://doi.org/10.1038/nclimate2641

MacDonald, G. M., Larsen, C. P., Szeicz, J. M., \& Moser, K. A. (1991). The reconstruction of boreal forest fire history from lake sediments: a comparison of charcoal, pollen, sedimentological, and geochemical indices. Quaternary Science Reviews, 10(1), 53-71. https://doi.org/10.1016/0277-3791(91)90030-X

Moore, P. D., Webb, J. A., \& Collison, M. E. (1991). Pollen analysis (2nd ed.). Blackwell scientific publications.

Naumov, I. V. (2006). The history of Siberia. London, New York: Routledge.

NOAA (2013). Ulgii Climate Normals 1961-1990. National Oceanic and Atmospheric Administration. Last updated 2013, accessed July 04, 2018.

Ponomarev, E. I., \& Kharuk, V. I. (2016). Wildfire occurrence in forests of the Altai-Sayan region under current climate changes. Contemporary Problems of Ecology, 9(1), 29-36. https://doi.org/10.1134/S199542551601011X

Rey, F., Gobet, E., Szidat, S., Lotter, A. F., Gilli, A., Hafner, A., \& Tinner, W., (2018). Radiocarbon wiggle matching on laminated sediments delivers high-precision chronologies. Radiocarbon, 1-21. https://doi.org/10.1017/RDC.2018.47

Rogers, J. D. (2012). Inner Asian States and Empires: theories and synthesis. Journal of Archaeological Research, 20(3), 205-256. https://doi.org/10.1007/s10814-011-9053-2 
Rose, N. L. (2015). Spheroidal carbonaceous fly ash particles provide a globally synchronous stratigraphic marker for the Anthropocene. Environmental science \& technology, 49(7), 4155-4162. https://doi.org/10.1021/acs.est.5b00543

830

831

832

833

834

835

836

837

838

839

840

841

842

843

844

845

846

847

848

849

850

851

852

853

854

855

856

857

858

859

860

861

862

863

864

865

866

867

Roth, R., \& Joos, F. (2013). A reconstruction of radiocarbon production and total solar irradiance from the Holocene ${ }^{14} \mathrm{C}$ and $\mathrm{CO}_{2}$ records: implications of data and model uncertainties. Climate of the Past, 9(4), 1879. https://doi.org/10.5194/cp-9-1879-2013

Rudaya, N. A., Tarasov, P. E., Dorofeyuk, N. I., Kalugin, I. A., Andreev, A. A., Diekmann, B., \& Daryin, A. V. (2008). Environmental changes in the Mongolian Altai during the Holocene. Archaeology, Ethnology and Anthropology of Eurasia, 36(4), 2-14. https://doi.org/10.1016/j.aeae.2009.03.001

Rudaya, N., Tarasov, P., Dorofeyuk, N., Solovieva, N., Kalugin, I., Andreev, A., Daryin, A., Diekmann, B., Riedel, F., Tserendash, N., \& Wagner, M. (2009). Holocene environments and climate in the Mongolian Altai reconstructed from the Hoton-Nur pollen and diatom records: a step towards better understanding climate dynamics in Central Asia. Quaternary Science Reviews, 28(5), 540-554. https://doi.org/10.1016/j.quascirev.2008.10.013

Sato, T., Kimura, F., \& Kitoh, A. (2007). Projection of global warming onto regional precipitation over Mongolia using a regional climate model. Journal of Hydrology, 333(1), 144-154. https://doi.org/10.1016/j.jhydrol.2006.07.023

Schlütz, F., Dulamsuren, C., Wieckowska, M., Mühlenberg, M., \& Hauck, M. (2008). Late Holocene vegetation history suggests natural origin of steppes in the northern Mongolian mountain taiga. Palaeogeography, Palaeoclimatology, Palaeoecology, 261(3), 203-217. https://doi.org/10.1016/j.palaeo.2007.12.012

Staubwasser, M., \& Weiss, H. (2006). Holocene climate and cultural evolution in late prehistoric-early historic West Asia. Quaternary Research, 66(3), 372-387. https://doi.org/10.1016/j.yqres.2006.09.001

Steinhilber, F., Beer, J., \& Fröhlich, C. (2009). Total solar irradiance during the Holocene. Geophysical Research Letters, 36(19). https://doi.org/10.1029/2009GL040142

Stockmarr, J. (1971). Tablets with spores used in absolute pollen analysis. Pollen et spores.

Stritch, L., Shaw, K., Roy , S. \& Wilson, B. (2014). Betula pendula. The IUCN Red List of Threatened $\quad$ Species 2014. http://dx.doi.org/10.2305/IUCN.UK.20143.RLTS.T62535A3115662.en.

Sun, A., Feng, Z., Ran, M., \& Zhang, C. (2013). Pollen-recorded bioclimatic variations of the last 22,600 years retrieved from Achit Nuur core in the western Mongolian Plateau. Quaternary international, 311, 36-43. https://doi.org/10.1016/j.quaint.2013.07.002

Tarasov, P., Dorofeyuk, N., \& Tseva, E. M. (2000). Holocene vegetation and climate changes in Hoton-Nur basin, northwest Mongolia. Boreas, 29(2), 117-126. https://doi.org/10.1111/j.1502-3885.2000.tb01205.X

Tchebakova, N. M., Blyakharchuk, T. A., \& Parfenova, E. I. (2009). Reconstruction and prediction of climate and vegetation change in the Holocene in the Altai-Sayan mountains, Central Asia. Environmental Research Letters, 4(4), 045025. https://doi.org/10.1088/17489326/4/4/045025 
Ter Braak, C. J., \& Prentice, I. C. (1988). A theory of gradient analysis. Advances in ecological research, 18, 271-317. https://doi.org/10.1016/S0065-2504(03)34003-6

Tian, F., Herzschuh, U., Dallmeyer, A., Xu, Q., Mischke, S., \& Biskaborn, B. K. (2013). Environmental variability in the monsoon-westerlies transition zone during the last 1200 years: lake sediment analyses from central Mongolia and supra-regional synthesis. Quaternary Science Reviews, 73, 31-47. https://doi.org/10.1016/j.quascirev.2013.05.005

Tian, F., Herzschuh, U., Mischke, S., \& Schlütz, F. (2014). What drives the recent intensified vegetation degradation in Mongolia-Climate change or human activity?. The Holocene, 24(10), 1206-1215. https://doi.org/10.1177/0959683614540958

Tinner, W., Conedera, M., Ammann, B., Gaggeler, H. W., Gedye, S., Jones, R., \& Sagesser, B. (1998). Pollen and charcoal in lake sediments compared with historically documented forest fires in southern Switzerland since $\mathrm{AD}$ 1920. The Holocene, 8(1), 31-42. https://doi.org/10.1191/095968398667205430

Tinner, W., Beer, R., Bigler, C., Clegg, B. F., Jones, R. T., Kaltenrieder, P., van Raden, U. J., Gilli, A., \& Hu, F. S. (2015). Late-Holocene climate variability and ecosystem responses in Alaska inferred from high-resolution multiproxy sediment analyses at Grizzly Lake. Quaternary Science Reviews, 126, 41-56. https://doi.org/10.1016/j.quascirev.2015.08.019

Tinner, W., \& Hu, F. S. (2003). Size parameters, size-class distribution and area-number relationship of microscopic charcoal: relevance for fire reconstruction. The Holocene, 13(4), 499-505. https://doi.org/10.1191/0959683603hl615rp

TPL (2018). The Plant List, http://www.theplantlist.org/tpl1.1/record/kew-21520. Last visited 12.07.2018.

Tsogtbaatar, J. (2004). Deforestation and reforestation needs in Mongolia. Forest Ecology and Management, 201(1), 57-63. https://doi.org/10.1016/j.foreco.2004.06.011

Tsogtbaatar, J. (2013). Deforestation and reforestation of degraded forestland in Mongolia. In: The Mongolian Ecosystem Network. Japan: Springer.

Uglietti, C., Zapf, A., Jenk, T. M., Sigl, M., Szidat, S., Salazar Quintero, G. A., \& Schwikowski, M. (2016). Radiocarbon dating of glacier ice: overview, optimisation, validation and potential. The Cryosphere, 10(6), 3091-3105. https://doi.org/10.5194/tc-10-3091-2016

Umbanhowar Jr, C. E., Shinneman, A. L., Tserenkhand, G., Hammon, E. R., Lor, P., \& Nail, K. (2009). Regional fire history based on charcoal analysis of sediments from nine lakes in western Mongolia. The Holocene, 19(4), 611-624. https://doi.org/10.1177/0959683609104039

Unkelbach, J., Dulamsuren, C., Punsalpaamuu, G., Saindovdon, D., \& Behling, H. (2018). Late Holocene vegetation, climate, human and fire history of the forest-steppe-ecosystem inferred from core G2-A in the 'Altai Tavan Bogd' conservation area in Mongolia. Vegetation history and Archaeobotany. https://doi.org/10.1007/s00334-017-0664-5

Volkov, V. V. (1995). Early nomads of Mongolia. In: Davis-Kimball, J., Bashilov, V. A., \& Yablonsky, L. T. (Eds.). Nomads of the Eurasian steppes in the early Iron Age. Berkeley: Zinat.

Walter, H. (1974). Die Vegetation Osteuropas, Nord-und Zentralasiens. VegetationsMonographien der Einzelnen Grossräume, Bd 7. Stuttgart: Gustav Fischer. 
Wang, W., \& Feng, Z. (2013). Holocene moisture evolution across the Mongolian Plateau and its surrounding areas: A synthesis of climatic records. Earth-Science Reviews, 122, 38-57. https://doi.org/10.1016/j.earscirev.2013.03.005

Wang, Y., Cheng, H., Edwards, R. L., He, Y., Kong, X., An, Z., Wu, J., Kelly, M. J., Dykoski, C. A., \& Li, X. (2005). The Holocene Asian monsoon: links to solar changes and North Atlantic climate. Science, 308(5723), 854-857. https://doi.org/10.1126/science.1106296

Wu, Z. Y. \& Raven P. H. (1999). Flora of China. Vol. 4 (Cycadaceae through Fagaceae). Beijing and St. Louis: Science Press and Missouri Botanical Garden Press.

Van Zeist, W., Woldring, H., \& Stapert, D. (2016). Late Quaternary vegetation and climate of southwestern Turkey. Palaeohistoria, 17, 53-143.

Xu, C., Liu, H., Anenkhonov, O. A., Korolyuk, A. Y., Sandanov, D. V., Balsanova, L. D., Naidanov, B. B., \& Wu, X. (2017). Long-term forest resilience to climate change indicated by mortality, regeneration, and growth in semiarid southern Siberia. Global change biology, 23(6), 2370-2382.

Zhao P, Xu C, Zhou M, Zhang B, Ge P, Zeng N, \& Liu H. (2018) Rapid regeneration offsets losses from warming-induced tree mortality in an aspen-dominated broad-leaved forest in northern China. PLoS ONE 13(4), e0195630. https://doi.org/10.1371/journal.pone.0195630 


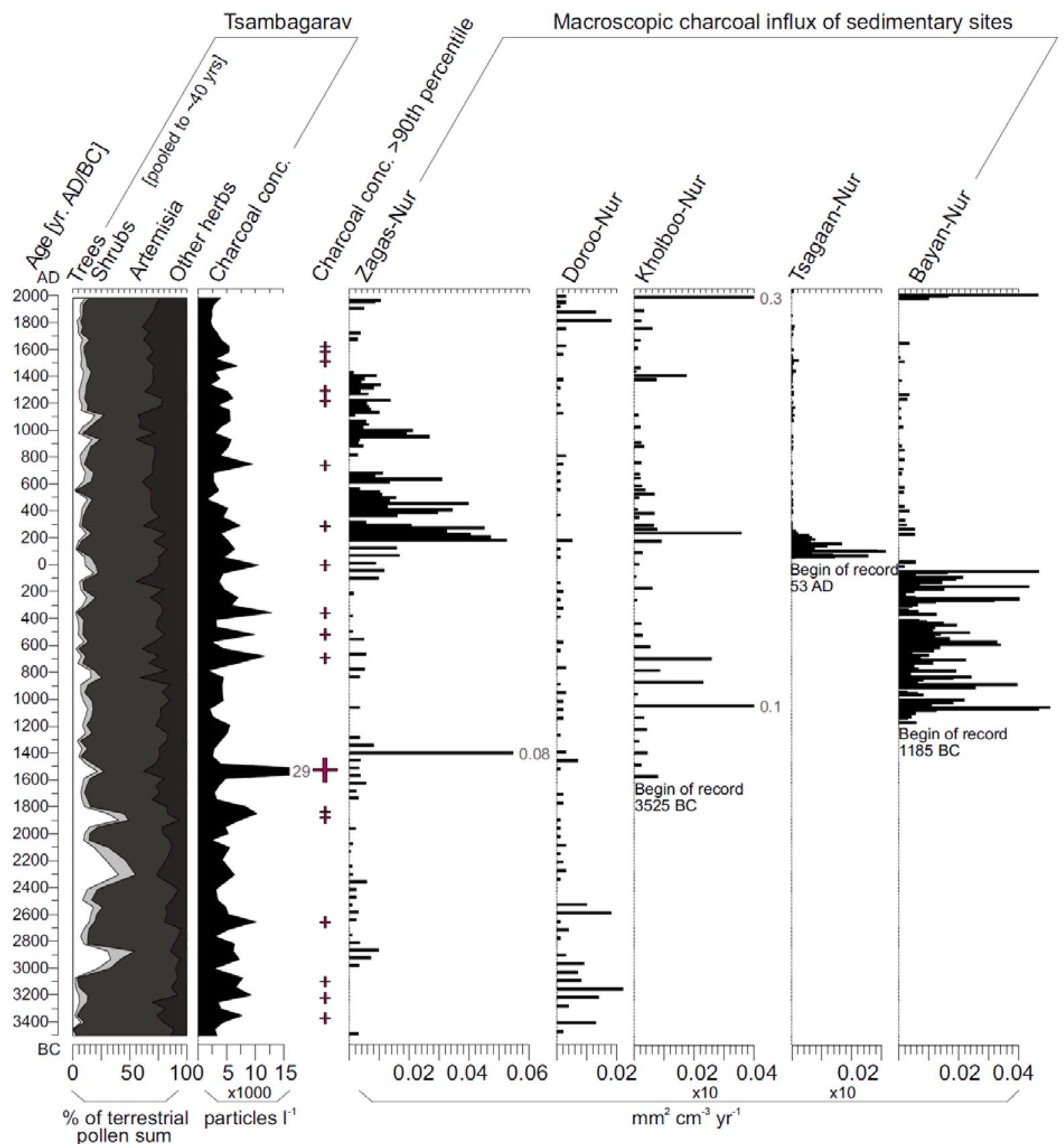

Figure A1 Comparison of Tsambagarav vegetation and fire reconstruction (charcoal concentrations and charcoal concentrations exceeding 90-percentile of all samples) with local fire reconstructions (macroscopic charcoal influx of particles $>180 \mu \mathrm{m}$ ) from lakes in western Mongolia (Umbanhowar et al., 2009) over the past 5500 years. 

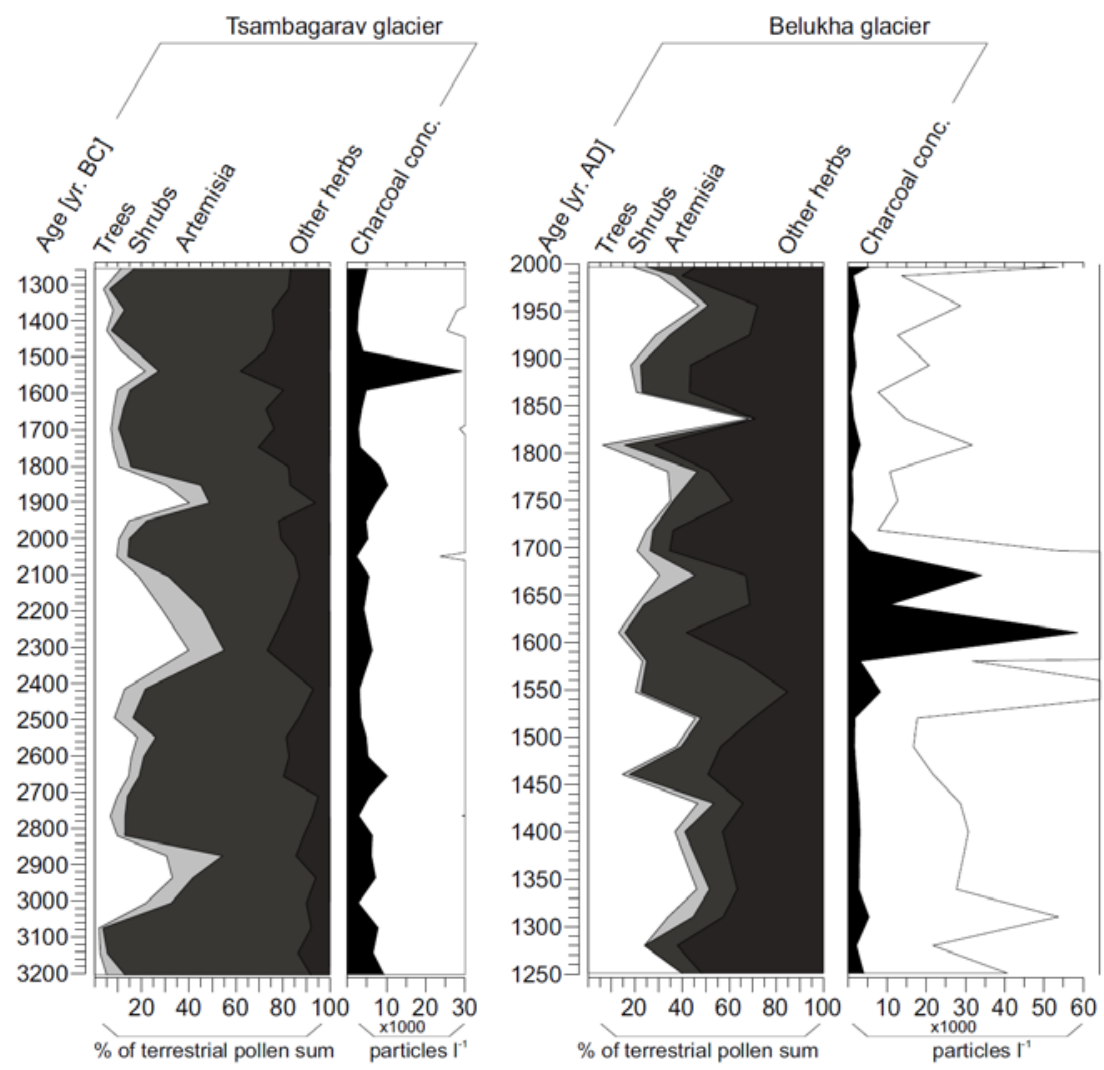

Figure A2 Comparison of forest phases recorded in glacier archives in the Mongolian and Russian Altai. Left: Tsambagarav main pollen diagram (percentages) and charcoal concentrations (particles $\mathrm{l}^{-1}$ ) during maximum afforestation (3000-1800 BC), right: Belukha main pollen diagram and charcoal concentrations 1250-1990 AD (Eichler et al., 2011). Hollow curves $=10 \mathrm{x}$ exaggeration. 